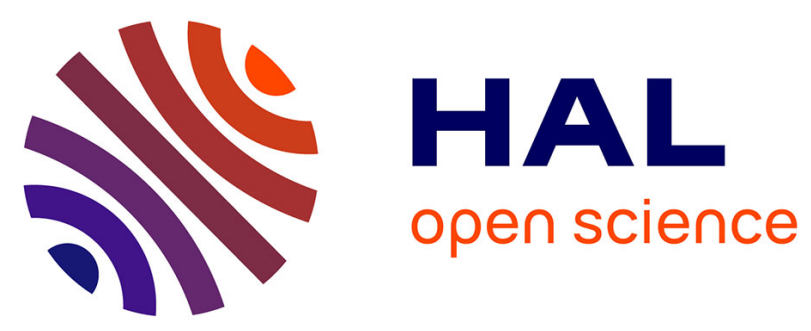

\title{
Evidence-based adverse outcome pathway approach for the identification of BPA as en endocrine disruptor in relation to its effect on the estrous cycle
}

Catherine Viguié, Sakina Mhaouty-Kodja, René Habert, Cécile Chevrier, Cécile Michel, Elodie Pasquier

\section{To cite this version:}

Catherine Viguié, Sakina Mhaouty-Kodja, René Habert, Cécile Chevrier, Cécile Michel, et al.. Evidence-based adverse outcome pathway approach for the identification of BPA as en endocrine disruptor in relation to its effect on the estrous cycle. Molecular and Cellular Endocrinology, 2018, 475, pp.10-28. 10.1016/j.mce.2018.02.007 . hal-01874553

HAL Id: hal-01874553

https://hal-univ-rennes1.archives-ouvertes.fr/hal-01874553

Submitted on 18 Sep 2018

HAL is a multi-disciplinary open access archive for the deposit and dissemination of scientific research documents, whether they are published or not. The documents may come from teaching and research institutions in France or abroad, or from public or private research centers.
L'archive ouverte pluridisciplinaire HAL, est destinée au dépôt et à la diffusion de documents scientifiques de niveau recherche, publiés ou non, émanant des établissements d'enseignement et de recherche français ou étrangers, des laboratoires publics ou privés. 


\section{TITLE}

\section{Evidence-based adverse outcome pathway approach for the identification of BPA as en endocrine disruptor in relation to its effect on the estrous cycle}

\section{AUTHORS}

Catherine Viguié*1 ${ }^{1}$, Sakina Mhaouty-Kodja*2, René Habert* ${ }^{3}$, Cécile Chevrier ${ }^{4}$, Cécile Michel $^{5}$, Elodie Pasquier ${ }^{5}$

Corresponding author: Elodie Pasquier, ANSES, 14 rue Pierre et Marie Curie, F-94701 Maisons-Alfort Cedex, France, elodie.pasquier@anses.fr

${ }^{1}$ Toxalim (Research Centre in Food Toxicology), INRA, ENVT, INP-Purpan, UPS, Toulouse, France

${ }^{2}$ Sorbonne Universités, UPMC Univ Paris 06, INSERM, CNRS, Neuroscience Paris Seine, Institut de Biologie Paris Seine, 75005 Paris, France.

${ }^{3}$ Genetic stability, stem cells and radiations, CEA, INSERM U 967, University Paris-

Diderot, CEA research center, Fontenay aux Roses, France

${ }^{4}$ INSERM, UMR1085, Researche Institute for Environmental and Occupational Health, Rennes, France

${ }^{5}$ ANSES, Risk Assessment Department, Maisons-Alfort, France

\section{KEYWORDS}

Bisphenol A, endocrine disruption, female reproduction, estrogen

\section{FUNDING/Declaration of interest}

\footnotetext{
Abbreviations: 2G: 2-generation study; 3G: 3-generation study; ANSES: Agence Nationale de Sécurité Sanitaire de I'alimentation, de I'environnement et du travail (French Agency for Food, Environmental and Occupational Health \& Safety) ; AOP: adverse outcome pathway; ARC: arcuate nucleus; AVPV: anteroventral periventricular nucleus; BMP-15: bone morphogenic protein 15; BPA: bisphenol A; bw: body weight; CL: corpora lutea; CREB: CAMP response element-binding protein; CYP45017a: 17ahydroxylase-17,20-desmolase (also named CYP17A1); CYP450arom: cytochrome P450 aromatase (also named CYP19A1); CYP450scc: P450 cholesterol side chain cleavage enzyme (also named CYP11A1); DES: diethylstilbestrol; DHEA: dehydroepiandrosterone; DiE-1: diestrus-1; $E_{2}$ : 17- $\beta$ estradiol; EB: estradiol benzoate; $\mathrm{ECHA}$ : European Chemical Agency; ED: endocrine disruptor; $\mathrm{EE}_{2}$ : ethinylestradiol; ER: estrogen receptor; EU: European Union; F: female; FSH: follicle stimulating hormone; GATA4: a transcription factor characterised by its ability to bind to the DNA sequence "GATA"; GD: gestation day; GDF-9: growth/differentiation factor 9; GnRH: gonadotrophin-releasing hormone; GPER: G protein-coupled estrogen receptor ; HPG: hypothalamic-pituitary-gonadal axis; HSD3 $\beta$ : 3 $\beta$-hydroxysteroid dehydrogenase; HSD17 $\beta: 173 \beta$-hydroxysteroid dehydrogenase; IGF-2: insulin-like growth factor 2; IVF: in vitro fertilization; KGN: human cell line from ovarian granulosa cell tumor; Kiss1R: kisspeptin receptor; LH: luteinising hormone; LRH1: liver receptor homolog $1 ; \mathrm{M}$ : male; MoA: mode of action; NTP: US National Toxicology Program; OVX: ovariectomised; PCNA: proliferating cell nuclear antigen; PCOS: polycystic ovary syndrome; PE: proestrus; PGF2a: prostaglandin F2-alpha; PII: proximal promoter II; PND: postnatal day; PPARY: Peroxisome Proliferator Activated Receptor gamma ; PPT: propyl pyrazoletriol (ERa agonist); PR: progesterone receptor; PRL: prolactin; RAC: Risk Assessment Committee; REACH: Registration, Evaluation, Authorisation and Restriction of Chemicals ; RP3V: rostral periventricular area of the third ventricle; RT-PCR: reverse transcription polymerase chain reaction; SD: Sprague Dawley; SF-1: steroidogenic factor 1 (transcription factor); SG-BPA : BPA specific gravity ; StAR: steroid acute regulatory protein; SVHC: substance of very high concern; T: testosterone; WHO: World Health Organization; WOE: Weight of Evidence.
} 
This review was carried out in the framework of assessments performed by the French Agency for Food, Environmental and Occupational Health and Safety (ANSES). The authors declare no conflict of interest.

\section{HIGHLIGHT}

- BPA alters ovarian steroidogenensis in adult females via aromatase reduction

- BPA fetal exposure is associated to altered estrous cyclicity

- BPA fetal exposure alters neuroendocrine functions critical for female reproduction

\section{ABSTRACT (150 words)}

Proper cyclicity is essential to reach successful optimal fertility. In rat and mice, BPA exposure is repeatedly and reliably reported to show an adverse effect on the estrous cycle after exposures at different life stages. In humans, a possible association between modifications of menstrual cycle characteristics (e.g. length of the cycle, duration of menstrual bleeding) and sub-fecundity or spontaneous abortion has been observed. Alterations of ovarian cyclicity can therefore be definitely considered as an adverse health outcome. As a prerequisite for the EU REACH regulation to identify a substance as an endocrine disruptor and thus a $\mathrm{SVHC}_{2}$, the proof has to be established that the substance can have deleterious health effects resulting from an endocrine mode of action. This review provides an overview of the currently available data allowing to conclude that the adverse effects of BPA exposure on ovarian cyclicity is mediated by an endocrine mode of action.

\footnotetext{
2 Substance of Very High Concern; make the substance eligible to the limitation of its uses to the obtention of conditional and temporary authorisations.
} 


\section{Context of the review}

Substances having endocrine disrupting (ED) properties may fulfil the definition of a Substance of Very High Concern (SVHC) under the European REACH regulation (EU Regulation $\left.N^{\circ} 1907 / 2006\right)$. Identifying a substance as an SVHC is a first step that opens the possibility for a stringent risk management measure that conditions its uses to the obtention of temporary authorisations and strongly encourages its substitution. The European Commission's Endocrine Disrupters Expert Advisory group agreed in 2013 on the elements for identification of an endocrine disruptor, in line with the WHO definition (JRC, 2013). To be identified as an endocrine disruptor a substance has to show endocrine mode of action, adverse health effects in individuals and/or their offspring and most importantly the link between the adverse effects and the endocrine mode of actions (MoA) has to be clearly established. In the aim of evaluating how the extensive database available on BPA fulfills the regulatory requirements for its identification as an endocrine disruptor, its effects on the female reproductive system have been reviewed and evaluated in relation to the evidence of an ED-mediated MoA.

Several experimental studies have investigated the effects of BPA on the reproductive system and reported a broad range of effects. In particular in females BPA has been consistently reported to induce ovarian toxicity. Although the effects of BPA on the follicular dynamic and/or oocyte maturation, two intimately linked physiological processes, might differ according to the period and mode of exposure, period of observation and specie, they are quite frequently reported in several animal species including sheep (Rivera et al., 2011; Veiga-Lopez et al., 2014), rats (Li et al., 2014; Gámez et al., 2015; Santamaría et al., 2016), and monkeys (Hunt et al., 2012). In mice and rats, exposure to BPA increases the incidence of cystic ovaries (Newbold et al., 2009; Signorile et al., 2010; Delclos et al., 2014; Newbold et al., 2007; Adewale et al., 2009; Fernández et al., 2009). Reduced ovarian weight or small ovaries, depletion of corpora lutea (Nikaido et al., 2004; Takagi et al., 2004; Newbold et al., 2007; Adewale et al., 2009; Nikaido et al., 2005) and of antral follicles (Delclos et al., 2014; Fernández et al., 2009) as well as decreases of the number of primordial follicles (Wang et al., 2014a; Rodríguez et al., 2010) are often, although not systematically, observed following developmental exposure to BPA. Concerning the oocytes development, meiotic abnormalities leading to aneuploidy were shown in several studies using different exposure scenarios. BPA can be associated to modifications of endocrine profiles and/or ovarian histology (Fernández et al., 2010; Newbold et al. 2007, 2009) very similar to the one encountered in Polycystic Ovarian Syndrom (PCOS) in women.

BPA exposure was also associated to changes in the reproductive tract morphology in several studies. Benign lesions like endometrial hyperplasia or atypical hyperplasia, which is a precursor lesion of adenocarcinoma, were reported in several studies in mice (Newbold et al., 2009 and 2007; Signorile et al., 2010; Hiyama et al., 2011). In some studies investigating the reproductive tract in older animals, more severe lesions were also found, including progressive proliferative lesions of the oviduct (Newbold et al., 2009). Malignant invasions (squamous metaplasia or polyps) were also described in 18month-old mice (Newbold et al., 2009 and 2007). An increased thickness of uterine epithelium and stroma and an increased incidence in cystic, hyperplastic and metaplastic endometrium are also reported in some studies in rats (Mendoza-Rodríguez et al., 2011; Delclos et al., 2014). A decline in reproductive capacity, i.e. a decrease in the number of pregnancies and/or a decrease in the number of pups born (decreased litter size), was observed in several studies when exposure of dams occurs in utero or during the first days of life in mice and rats (Wang et al., 2014a; Cabaton et al., 2011; Fernández et al., 2009; Varayoud et al., 2011). Exposure to BPA during adulthood consistently results in a decrease in the number of pregnancies and implantations in several studies (MooreAmbritz et al., 2015; Berger et al., 2008 and 2010; Al Hiyasat et al., 2004; NTP, 1985).

Some of the parameters related to the female reproductive function potentially linked to 
estrous cyclicity were also investigated in epidemiological studies in human. Highest levels of BPA were associated with implantation failures in women undergoing medicallyassisted procreation (Ehrlich et al., 2012). Decreased ovarian function as part of an in vitro fertilisation (IVF) was also reported with higher BPA exposure in two studies (Fujimoto et al., 2011; Mok-Lin et al., 2010). In a cohort of women undergoing infertility treatments, a decreasing number of antral follicles was observed in association with increasing BPA exposure (Souter et al., 2013). An association of shorter luteal phases with the concurrent BPA exposure was observed among women with no known fertility problems (Jukic et al., 2015).

The aim of the present paper was not to provide one more review on the effect of BPA on the female reproductive system. There are already several very good reviews on that topic. Our specific goal was to assess whether WOE approach along with AOP could be used to show that BPA could fulfill the EU criteria for the identification as an ED. It was thus decided to focus on adverse effects acknowledged by a harmonised classification according to the CLP Regulation 3 , i.e. BPA effects on female reproductive system and fertility (ECHA, 2014). More precisely, it was decided to focus on the recognized adverse effect of BPA on estrous cyclicity since it is a reproductive process with a well known physiological scheme of regulation proceeding from undiscutable endocrine determinism.

\section{Method for literature screening and working database constitution}

As a prerequisite for a WOE approach, an extensive literature database was built. It first included all references anterior to 2012 at the time when the bibliography review for the classification proposal stops. Then, all studies from academic and/or private scientific research as well as reports from regulatory bodies published on BPA effect on female reproductive function from 2012 to may 2016 have been gathered using PubMed-NCBI and/or Web Of Science ${ }^{T M}$ core collection. The search strategy was based on different combinations of the following truncated key-words: BPA, female, reproducti*, ovar*, neuroendocrine, endocrine disrupt*, estrous cycle, estrus. Toxicological studies presenting major biases as listed thereafter were excluded from the list: absence of negative control, too low number of animals, improper statistical analysis, data not shown, poor monitoring of estrous cyclicity. For epidemiological studies, the major biases leading to exclusion were based on the size of the population together with scheme of the study. Neither the absence of positive controls nor using a non phyto-estrogen free diet was considered as major biases.

This database was merged with the first one, and the total database was scrutinized for studies including characterisation of estrous cyclicity (table 1). This subset of studies was used to determine if there were some concerns that the effect of BPA on estrous cyclicity might be challenged or a matter of debate at the sight of the new data. The percentage of studies with positive results was determined for each period of exposure all species confounded. Interestingly, in agreement with the evaluation of BPA by the French agency ANSES in 2013 (in its annexe), the effects of BPA on the estrous cycle appeared to be the most obvious following exposure during or after the postnatal period. Indeed, about $80 \%$ of the studies with such exposures showed positive results. When considering any window of exposure more than $50 \%$ of all the studies showed positive results and it was thus assumed that there was no serious reason to dismiss the effect of BPA on the estrous cycle. During the course of its evaluation in 2008, the NTP considered that there was not enough evidence to recognize the effect of BPA on estrous cyclicity. It is noteworthy that since then, studies such as Ziv-Gal et al. (2015) and European bodies

${ }_{3}$ Regulation (EC) No 1272/2008 of the European Parliament and of the Council of 16 December 2008 on classification, labelling and packaging of substances and mixtures 
such as RAC (opinion published in March 2014 (ECHA, 2014)), have concluded "that BPA exerts its toxic effects on the ovaries, either due to direct effects on the ovaries or indirectly via effects on the HPO-axis. [...] The guideline studies did not report any significant effects on the oestrous cyclicity. However, in the NCTR (2013) study [referred as Delclos et al., 2014 in the present article] and in most of the studies using subcutaneous dosing, BPA induced irregularities in the oestrus cycle (Mendoza-Rodríguez et al., 2011, Kato et al., 2003; Fernández et al., 2009)."

In a second step, this same subset of studies was used to identify those studies in which evidence(s) for endocrine mode of action was reported together with estrous cycle impairement (tables 3 and 5). The total data base was then scrutinized for other studies including in vitro experimentations that could confort those hypothetical modes of action thus reinforcing our Adverse Outcome pathway analysis.

In relation to the WHO definition of an endocrine disruptor, the following aspects are successively discussed in this review: evidence of an adverse health effects, evidence of an endocrine mode of action (MoA), discussion of the plausible link between adverse effect and endocrine MoA, and finally human relevance. More details on the rating and weight of evidence is available in the introduction paper of this review.

\section{Evidences supporting the identification of the alteration of estrous cyclicity as an adverse effect of BPA}

\subsection{Non-human information}

Experimental studies investigating the effects of exposure to BPA on estrous cyclicity are summarised in Table 1. Reliable results were reported in several experimental studies showing an adverse effect of BPA on the estrous cycle, including irregular and prolonged cycles. One should look at these results bearing in mind the current toxicological reference values recommended at the EU level. Following a reassessment of the database in 2015, EFSA proposed a new health-based guidance value for BPA (EFSA, 2015). A t-TDI of $4 \mu \mathrm{g} \mathrm{BPA} / \mathrm{kg}$ bw based on a BMD L10 ((Benchmark Dose $10 \%$ Lower Confidence Limit) of $8.96 \mathrm{mg} / \mathrm{kg}$ bw (body weight) per day in mice.

Table 1: Summary table of studies investigating the effects of BPA on the estrous cycle in female animals

\begin{tabular}{|c|c|c|c|c|}
\hline Reference & Species & Routes & $\begin{array}{l}\text { Dose } \\
\text { Exposure period }\end{array}$ & Effect on estrous cycle \\
\hline \multicolumn{5}{|c|}{ Gestational exposure } \\
\hline \multicolumn{5}{|l|}{ Mouse studies } \\
\hline Honma et al., 2002 & $\begin{array}{l}\text { ICR JCl } \\
\text { mouse }\end{array}$ & Subcutaneous & $\begin{array}{l}0,2,20 \mu \mathrm{g} / \mathrm{kg} \text { bw/d } \\
\mathrm{GD} 11-\mathrm{GD} 17\end{array}$ & $\begin{array}{l}\lambda \text { length of the estrous cycle of } 1 \\
\text { day at both doses }(p \leq 0.05) \text {. }\end{array}$ \\
\hline Nikaido et al., 2004 & $\begin{array}{l}\text { CD-1 } \\
\text { mouse }\end{array}$ & Subcutaneous & $\begin{array}{l}0,0.5,10 \mathrm{mg} / \mathrm{kg} \mathrm{bw} / \mathrm{d} \\
\text { GD15-GD19 }\end{array}$ & $\begin{array}{l}\text { Increased cycle length of } 3 \text { days } \\
\text { in both groups with increased } \\
\text { time of diestrus }(p<0.01)\end{array}$ \\
\hline Wang et al., 2014a & $\begin{array}{l}\text { FVB } \\
\text { mouse }\end{array}$ & Oral (gavage) & $\begin{array}{l}0,0.5,20 \text { or } 50 \mu \mathrm{g} / \mathrm{kg} \\
\text { bw/d } \\
\text { GD11-PND0 }\end{array}$ & $\begin{array}{l}\lambda \text { time in diestrus and metestrus } \\
\text { and } \searrow \text { in proestrus and estrus at } \\
0.5 \mu \mathrm{g} / \mathrm{kg}\end{array}$ \\
\hline
\end{tabular}




\begin{tabular}{|c|c|c|c|c|}
\hline & & & & $\begin{array}{l}У \text { in estrus at } 20 \mu \mathrm{g} / \mathrm{kg} \\
\text { No significant effect at } 50 \mu \mathrm{g} / \mathrm{kg} \\
\text { ( } \pi \text { time in metestrus and } \searrow \text { in } \\
\text { proestrus with DES) }\end{array}$ \\
\hline \multicolumn{5}{|l|}{ Rat studies } \\
\hline Tinwell et al., 2002 & $\begin{array}{l}\text { Sprague } \\
\text { Dawley } \\
\text { and } \\
\text { Alderley } \\
\text { park } \\
\text { (derived } \\
\text { from } \\
\text { Wistar) } \\
\text { rat } \\
\end{array}$ & Oral (gavage) & $\begin{array}{l}0,0.02,0.1 \text { or } 50 \mathrm{mg} / \mathrm{kg} / \mathrm{d} \\
\text { GD6-GD21 }\end{array}$ & $\begin{array}{l}\text { No difference in the stage of the } \\
\text { estrous cycles at PND90. }\end{array}$ \\
\hline \multicolumn{5}{|l|}{ Sheep studies } \\
\hline $\begin{array}{l}\text { Savabieasfahani et al., } \\
2006\end{array}$ & $\begin{array}{l}\text { Suffolk } \\
\text { sheep }\end{array}$ & $\begin{array}{l}\text { Subcuta- } \\
\text { neous }\end{array}$ & $\begin{array}{l}0 \text { or } 5 \mathrm{mg} / \mathrm{kg} \mathrm{bw} / \mathrm{d} \\
\text { GD30 - GD90 }\end{array}$ & $\begin{array}{l}\text { No effect on the length of } \\
\text { progestogenic cycles } \downarrow \text { of the } \\
\text { amplitude of the LH preovulatory } \\
\text { surge following PGF2 } \alpha \text {-induced } \\
\text { luteolysis. }\end{array}$ \\
\hline $\begin{array}{l}\text { Veiga-Lopez et al., } \\
2014\end{array}$ & $\begin{array}{l}\text { Suffolk } \\
\text { sheep }\end{array}$ & subcutaneous & $\begin{array}{l}0.05,0.5, \text { or } \\
5 \mathrm{mg} / \mathrm{kgBW} / \text { day GD30 - } \\
\text { GD90 }\end{array}$ & $\begin{array}{l}\text { In } 19 \text { months old offspring: } \downarrow \text { time } \\
\text { intervall between E2 and LH } \\
\text { surges (vehicle vs BPA, all groups } \\
\text { confounded). }\end{array}$ \\
\hline \multicolumn{5}{|c|}{ Perinatal exposure } \\
\hline Mouse study & & & & \\
\hline Naulé et al., 2014 & $\begin{array}{l}\text { C57BL/6] } \\
\text { mouse }\end{array}$ & Oral (gavage) & $\begin{array}{l}0,0.05 \text { or } 5 \mathrm{mg} / \mathrm{kg} / \mathrm{d} \\
\text { GD15 to PND21 }\end{array}$ & $\begin{array}{l}\text { Normal cycle analysed after } \\
\text { PND60 }\end{array}$ \\
\hline \multicolumn{5}{|l|}{ Rat studies } \\
\hline Kwon et al., 2000 & $\begin{array}{l}\text { Sprague } \\
\text { Dawley } \\
\text { rat }\end{array}$ & Oral (gavage) & $\begin{array}{l}0,3.2,32 \text { or } 320 \mathrm{mg} / \mathrm{kg} / \mathrm{d} \\
\text { GD } 11-\text { PND } 20\end{array}$ & $\begin{array}{l}\text { No effect in 4-month F1 } \\
\text { (irregular estrous cycle with DES) }\end{array}$ \\
\hline Rubin et al., 2001 & $\begin{array}{l}\text { Sprague } \\
\text { Dawley } \\
\text { rat }\end{array}$ & $\begin{array}{l}\text { Oral (drinking } \\
\text { water) }\end{array}$ & $\begin{array}{l}0,0.1,1.2 \\
\mathrm{mg} / \mathrm{kg} \mathrm{bw} / \mathrm{d} \\
\mathrm{GD} 6-\text { end of lactation } \\
\text { period }\end{array}$ & $\begin{array}{l}\text { Irregular cycles in } 79 \% \text { (4-week } \\
\text { old) and } 77 \% \text { (6-month old) F1 } \\
\text { at the high dose (significant). No } \\
\text { significant effect at low dose. } \\
\text { Intermittent extended period of } \\
\text { diestrus, or extended period of } \\
\text { proestrus and/or estrus. }\end{array}$ \\
\hline Takagi et al., 2004 & $\begin{array}{l}\text { Sprague } \\
\text { Dawley } \\
\text { rat }\end{array}$ & Oral & $\begin{array}{l}0,7,70 \text { or } 300 \mathrm{mg} / \mathrm{kg} \\
\text { bw/d (approx.) } \\
\text { GD15 - PND10 }\end{array}$ & $\begin{array}{l}\text { No effect on estrous cyclicity } \\
\text { (some animals with extended } \\
\text { diestrus in the low dose group } \\
\text { but not significant) }\end{array}$ \\
\hline Yoshida et al., 2004 & $\begin{array}{l}\text { Donryu } \\
\text { rat }\end{array}$ & Oral gavage & $\begin{array}{l}0,0.006 \text { or } 6 \mathrm{mg} / \mathrm{kg} \mathrm{bw} / \mathrm{d} \\
\mathrm{GD} 2-\text { PND21 }\end{array}$ & No effect on estrous cyclicity \\
\hline $\begin{array}{l}\text { Mendoza- Rodríguez et } \\
\text { al., } 2011\end{array}$ & $\begin{array}{l}\text { Wistar } \\
\text { rat }\end{array}$ & $\begin{array}{l}\text { Oral (drinking } \\
\text { water) }\end{array}$ & $\begin{array}{l}1.2 \mathrm{mg} / \mathrm{kg} \mathrm{bw} / \mathrm{d} \\
\mathrm{GD} 6-\mathrm{PND} 21\end{array}$ & $\begin{array}{l}\text { Observations in 3-month old } \\
\text { females : } 79 \% \text { with irregular } \\
\text { cycles vs } 6 \% \text { in controls } \\
\text { (determined on } 4 \text { consecutive } \\
\text { weeks) characterised mainly by } \\
\text { several continuous estrus days } \\
\text { and in few animals persistent } \\
\text { diestrus. }\end{array}$ \\
\hline Delclos et al., 2014 & $\begin{array}{l}\text { Sprague- } \\
\text { Dawley } \\
\text { rat }\end{array}$ & $\begin{array}{l}\text { Oral gavage } \\
\text { (aqueous } \\
\text { solution) }\end{array}$ & $\begin{array}{l}2.5,8,25,80,260,840, \\
2700 \mu \mathrm{g} / \mathrm{kg} \mathrm{bw} / \mathrm{d} \text { and } 100 \\
\text { and } 300 \mathrm{mg} / \mathrm{kg} \mathrm{bw} / \mathrm{d} \\
\text { GD6- PND90 }\end{array}$ & $\begin{array}{l}\text { Observation between PND } 69 \text { to } \\
90: \\
\text { At } 300 \mathrm{mg} / \mathrm{kg}, \pi \text { incidence of } \\
\text { animals with abnormal cycles } \\
\text { primarily due to extended estrus } \\
\text { and extended estrus/diestrus. } \\
\text { Between PND } 150 \text { and } 170, \pi \\
\text { incidence of abnormal cycles } \\
\text { from } 100 \mathrm{mg} / \mathrm{kg} \text {. } \\
\text { Effect similar to } \mathrm{EE}_{2} \text {. }\end{array}$ \\
\hline Ferguson et al., 2014 & $\begin{array}{l}\text { Sprague } \\
\text { Dawley } \\
\text { rat }\end{array}$ & Oral (gavage) & $\begin{array}{l}0,2.5 \text { or } 25 \mu \mathrm{g} / \mathrm{kg} / \mathrm{d} \\
\text { GD6 to PND21 }\end{array}$ & $\begin{array}{l}\text { No effect on the proportion of } \\
\text { days spent in each phase (lower } \\
\text { proportion of days in diestrus } \\
\text { with } E_{2} \text {, extended estrus } \\
\text { transitions) }\end{array}$ \\
\hline
\end{tabular}


ACCEPTED MANUSCRIPT

\begin{tabular}{|c|c|c|c|c|}
\hline \multicolumn{5}{|l|}{ Mouse study } \\
\hline Nah et al., 2011 & $\begin{array}{l}\text { ICR } \\
\text { mouse }\end{array}$ & Subcutaneous & $\begin{array}{l}0,0.1,1,10,100 \mathrm{mg} / \mathrm{kg} \\
\text { bw } \\
\text { PND8 }\end{array}$ & $\begin{array}{l}\text { y number of estrus days at the } \\
\text { high dose (examined during } 9 \\
\text { days from PND20) }\end{array}$ \\
\hline \multicolumn{5}{|l|}{ Rat studies } \\
\hline Kato et al., 2003 & $\begin{array}{l}\text { Sprague- } \\
\text { Dawley } \\
\text { rats }\end{array}$ & Subcutaneous & $\begin{array}{l}0,0.25,1 \text { or } 4 \mathrm{mg} / \mathrm{pups} \\
\text { PND0 - PND9 }\end{array}$ & $\begin{array}{l}\text { Observation from PND } 61 \text { to } 94 \text { : } \\
\text { irregular estrous cycles in } 4 / 6 \\
\text { females and persistent estrus in } \\
2 / 6 \text { at } 4 \mathrm{mg} / \mathrm{kg} \text {; (similar effects } \\
\text { with } 10 \mu \mathrm{g} / \mathrm{kg} \mathrm{E} \mathrm{E}_{2} \text { ) }\end{array}$ \\
\hline Adewale et al., 2009 & $\begin{array}{l}\text { Long- } \\
\text { Evans rat }\end{array}$ & Subcutaneous & $\begin{array}{l}0,50 \mu \mathrm{g} / \mathrm{kg} \mathrm{bw} / \mathrm{d} \text { or } 50 \\
\mathrm{mg} / \mathrm{kg} \mathrm{bw/d} \\
\text { PND1- PND3 }\end{array}$ & $\begin{array}{l}\text { At } 50 \mu \mathrm{g} / \mathrm{kg}: 14 \% \text { of females } \\
\text { were not cycling anymore by } 15 \\
\text { weeks after vaginal opening. } \\
\text { At } 50 \mathrm{mg} / \mathrm{kg}: 67 \% \text { of females } \\
\text { were not cycling anymore by } 15 \\
\text { weeks after vaginal opening. } \\
(100 \% \text { in controls) }\end{array}$ \\
\hline Fernández et al., 2009 & $\begin{array}{l}\text { Sprague } \\
\text { Dawley } \\
\text { rat }\end{array}$ & Subcutaneous & $\begin{array}{l}0,6,2 / 2,5,62.5 / 25 \mathrm{mg} / \mathrm{kg} \\
\text { bw/d } \\
\text { PND1- PND10 }\end{array}$ & $\begin{array}{l}\text { Irregular estrus cycle in adult F1 } \\
\text { at high dose with high prevalence } \\
\text { of estrus after PND90 }(\mathrm{p}<0.05)\end{array}$ \\
\hline Monje et al., 2010 & $\begin{array}{l}\text { Wistar } \\
\text { rats }\end{array}$ & Subcutaneous & $\begin{array}{l}0,0.05 \text { or } 20 \mathrm{mg} / \mathrm{kg} \mathrm{bw} / \mathrm{d} \\
\text { PND1-PND7 }\end{array}$ & $\begin{array}{l}\text { Observations of females for } 2 \\
\text { weeks from PND85: } \\
\pi \text { in proestrous/estrous time } \\
(p<0.001) \text { at } 0.05 \mathrm{mg} / \mathrm{kg} \text { (high } \\
\text { dose not examined for cyclicity) }\end{array}$ \\
\hline Franssen et al., 2016 & $\begin{array}{l}\text { Wistar } \\
\text { rats }\end{array}$ & Subcutaneous & $\begin{array}{l}0,25 \mathrm{ng} / \mathrm{kg} \text { or } 5 \mathrm{mg} / \mathrm{kg} \text { bw } \\
\text { PND1 - PND5 or PND15 }\end{array}$ & $\begin{array}{l}\text { Observations from VO to PND } \\
80: \text { no effect on estrous cyclicity }\end{array}$ \\
\hline \multicolumn{5}{|c|}{ Prepubertal exposure } \\
\hline Mouse study & & & & \\
\hline Nikaido et al., 2005 & $\begin{array}{l}\text { ICR } \\
\text { mouse }\end{array}$ & $\begin{array}{l}\text { Subcuta- } \\
\text { neous }\end{array}$ & $\begin{array}{l}0 \text { or } 10 \mathrm{mg} / \mathrm{kg} \mathrm{bw} / \mathrm{d} \\
\text { PND } 15 \text { to } 18\end{array}$ & $\begin{array}{l}\text { No effect on the estrus cycle } \\
\text { during } 5-8,9-12 \text { and } 21-24 \\
\text { weeks of age. }\end{array}$ \\
\hline \multicolumn{5}{|l|}{ Rat study } \\
\hline Zaid et al., 2014 & $\begin{array}{l}\text { Sprague- } \\
\text { Dawley } \\
\text { rats }\end{array}$ & Oral (gavage) & $\begin{array}{l}0 \text { or } 10 \mathrm{mg} / \mathrm{kg} / \mathrm{d} \\
\text { For } 42 \text { days from PND28 }\end{array}$ & $\begin{array}{l}\text { Only } 3 / 8 \text { rats with normal cycles } \\
(p<0.05) \text { and } 5 / 8 \text { rats with } \\
\text { persistent diestrous }(p<0.05)\end{array}$ \\
\hline \multicolumn{5}{|c|}{ Adult exposure } \\
\hline \multicolumn{5}{|l|}{ Mouse study } \\
\hline $\begin{array}{l}\text { Moore-Ambritz et al., } \\
2015\end{array}$ & $\begin{array}{l}\text { C57BL/6 } \\
\text { mouse }\end{array}$ & Oral (gavage) & $\begin{array}{l}0 \text { or } 50 \mu \mathrm{g} / \mathrm{kg} / \mathrm{d} \\
\text { For } 12-15 \text { days from day } \\
\text { of } 1^{\text {st }} \text { estrus (approx. } \\
\text { PND39) }\end{array}$ & $\begin{array}{l}\text { No effect on duration of each } \\
\text { estrous stage during the dosing } \\
\text { period (lengthened cycle with } \\
\text { DES). }\end{array}$ \\
\hline \multicolumn{5}{|c|}{ Rat studies } \\
\hline Laws et al., 2000 & $\begin{array}{l}\text { Long } \\
\text { Evans rat }\end{array}$ & Oral (gavage) & $\begin{array}{l}0 \text { or } 100 \mathrm{mg} / \mathrm{kg} \text { for } 25 \\
\text { days in cycling animals }\end{array}$ & $\begin{array}{l}\downarrow \text { number of } 4-5 \text { day cycles } \\
(p<0.05) \text {. Extended diestrus in } 6 \\
\text { animals, extended estrus in } 2 \\
\text { animals, normal cycles in } 7 \\
\text { animals. } \\
\text { (similar effects but more } \\
\text { pronounced with } \mathrm{E}_{2} \text { ) }\end{array}$ \\
\hline Lee et al., 2013 & $\begin{array}{l}\text { Sprague- } \\
\text { Dawley } \\
\text { rat }\end{array}$ & Oral (gavage) & $\begin{array}{l}0,0.001 \text { or } 0.1 \mathrm{mg} / \mathrm{kg} \\
\text { bw/d } \\
8 \text {-week animals exposed } \\
\text { for } 90 \text { days }\end{array}$ & $\begin{array}{l}\text { Observations of female for } 30 \\
\text { days after the } 90 \text {-day exposure: } \\
\pi \text { in duration of the estrus } \\
\text { phase: } p<0.001 \text { at } 0.001 \mathrm{mg} / \mathrm{kg}, \\
\mathrm{p}<0.01 \text { at } 0.1 \mathrm{mg} / \mathrm{kg} \text { and } \mathrm{p}<0.05 \\
\text { with EB } \\
\text { No animal in a persistent estrus } \\
\text { phase. }\end{array}$ \\
\hline \multicolumn{5}{|c|}{ Multi-generation studies } \\
\hline \multicolumn{5}{|l|}{ Mouse studies } \\
\hline NTP, 1985 & $\begin{array}{l}\mathrm{CD}-1 \\
\text { mouse }\end{array}$ & $\begin{array}{l}\text { Oral } \\
\text { (diet) }\end{array}$ & $\begin{array}{l}0,300 / 350,600 / 650 \text { or } \\
1200 / 1300 \mathrm{mg} / \mathrm{kg} / \mathrm{d}(\mathrm{M} / \mathrm{F} \text { ) } \\
1 \text { week before mating until } \\
\text { sacrifice } \\
\text { (continuous breeding; } 2 \mathrm{G} \text { ) }\end{array}$ & No effect on estrous cycle \\
\hline Tyl et al., 2008 & $\begin{array}{l}\mathrm{CD}-1 \\
\text { mouse }\end{array}$ & Oral (gavage) & $\begin{array}{l}0.003,0.03,0.3,5,50 \text { or } \\
600 \mathrm{mg} / \mathrm{kg} / \mathrm{d} \\
8 \text { weeks before mating to }\end{array}$ & $\begin{array}{l}\text { F0 treated females were twice } \\
\text { more in estrus as compared to } \\
\text { controls at } 600 \mathrm{mg} / \mathrm{kg}\end{array}$ \\
\hline
\end{tabular}




\begin{tabular}{|c|c|c|c|c|}
\hline & & & $\begin{array}{l}\text { adulthood } \\
(2 \mathrm{G})\end{array}$ & \\
\hline \multicolumn{5}{|l|}{ Rat studies } \\
\hline Ema et al., 2001 & $\begin{array}{l}\text { Sprague- } \\
\text { Dawley } \\
\text { rat }\end{array}$ & $\begin{array}{l}\text { Oral (gavage } \\
\text { until weaning } \\
(2 \mathrm{G})\end{array}$ & $\begin{array}{l}0,0.2,2,20 \text { or } 200 \\
\mu \mathrm{g} / \mathrm{kg} / \mathrm{d} \\
10(\mathrm{M}) \text { or } 2(\mathrm{~F}) \text { weeks }\end{array}$ & No effect \\
\hline Tyl et al., 2002 & $\begin{array}{l}\text { Sprague- } \\
\text { Dawley } \\
\text { rat }\end{array}$ & Oral (diet) & $\begin{array}{l}0.001,0.02,0.3,5,50 \text { or } \\
500 \mathrm{mg} / \mathrm{kg} / \mathrm{d} \\
10 \text { weeks before mating } \\
\text { until PND21 } \\
(3 \mathrm{G})\end{array}$ & No effect on estrous cycle length. \\
\hline
\end{tabular}

It is important to note that the effects of BPA exposure on the estrous cycle were analyzed, in the majority of rodent studies, in relatively young adult females (less than six months of age). A previous study showed that deleterious effects of BPA exposure on reproductive functions may be more significant at advanced ages (Cabaton et al., 2011). This, together, with differences between studies in terms of experimental conditions, strain, period of exposure as explained above... may explain the variability of BPA effects.

In its opinion of March 2014 (ECHA, 2014) in support of classification of BPA as Repr 1B - H360F, the Risk Assessment Committee (RAC) produced the following conclusions on estrous cycle disturbances in experimental studies:

"Three of the guideline studies (NTP, 1985, Tyl et al., 2002, 2008, Ema et al., 2001) did not report any significant effects on the oestrous cyclicity. However, in Tyl et al., 2008, a higher percentage of the high-dose females were in oestrus as compared to controls.

Furthermore, in the [Delclos et al. (2014)] study, in which SD rats were exposed during GD6-PND90, 63\% of the animals in the high-dose group had an asynchronous oestrous cyclicity versus $12 \%$ in the vehicle control. It was noted by RAC that the control vehicle group was also affected as compared to the naïve controls ( $0 \%$ asynchronous estrous cyclicity). Based on vaginal cytology, disruption of the oestrous cycle at the highest BPA dose was reported on PND69-90 and at the two highest doses on PND150-170 in a similar manner as for the positive control $\left(E E_{2}\right)$. The increase of the proportion of animals showing asynchronous estrous cycle on PND150-170 was statistically significant at $100 \mathrm{mg} / \mathrm{kg}$ bw/day $(n=14)$, but not at $300 \mathrm{mg} / \mathrm{kg}$ bw/day $(n=7)$. Maternal toxicity in this study included a significant reduction in body weight gain (6-13\% with an average at $10 \%$ ) at PND4 and beyond in the two BPA high dose groups. No effect on body weight gain was observed in low dose groups.

Several of the remaining non-guideline studies reported BPA-induced irregularities in the oestrus cycle (Mendoza-Rodríguez et al., 2011, Kato et al., 2003; Fernández et al., 2009).

In contrast, in the study by Kwon et al. (2000), in which SD rats were exposed via oral gavage to 3.2, 32 or $320 \mathrm{mg} \mathrm{BPA} / \mathrm{kg}$ bw/day between GD11 and PND20, no effects were reported on the oestrous cycle.

RAC concluded that BPA-treated FO females were twice more in estrus as compared to controls at $600 \mathrm{mg} / \mathrm{kg}$ in Tyl et al. (2008), and that BPA induced irregularities in the oestrus cycle also in the [Delclos et al. (2014)] study and in most of the studies using subcutaneous dosing (Mendoza-Rodríguez 2011, Kato et al. 2003; Fernández et al. 2009)."

\subsection{Human information}

The link between BPA, human exposure and cycle parameters in women has been studied in a single recent study. 
In the mid-80's, 221 women with no fertility disorders were enrolled at the time they stopped contraceptive method to become pregnant and followed for up to 6 months as a population-based cohort (Jukic et al. 2015). Daily first-void morning urine samples were collected for hormonal measurements, the ovulation day recorded; the plausible conception day and early pregnancy loss were calculated. BPA was measured in weekly samples pooled over one cycle.

Total BPA urinary concentration of a given cycle was negatively correlated with the duration of the luteal phase comtemporary of the BPA measurement. When looking for associations with BPA concentration of the previous cycle, no association was found with the length of the follicular or luteal phases.

The study and its design are considered as of overall good quality although it should be noted that it is common that women experience instability in the first cycles after cessation of contraception.

Based on this single epidemiological study, no robust conclusion can be drawn on the effect of BPA on the estrous cycle in women.

\subsection{Summary and discussion of alteration of estrous cyclicity as an adverse effect}

An alteration of estrous cycles by BPA is identified in many experimental studies in rats and mice after exposure at different life stages.

This effect was recognised by RAC in its opinion in support of classification of BPA as Repr. 1B - H360F as summarised in the RAC opinion on restriction of BPA (ECHA 2015):

"RAC's opinion (RAC 2014) was based on adverse effects, such as disturbances in the oestrous cycle, at a dose of $600 \mathrm{mg} / \mathrm{kg} \mathrm{bw/day} \mathrm{(Tyl} \mathrm{et} \mathrm{al.,} \mathrm{2008)} \mathrm{and} \mathrm{at} \mathrm{a} \mathrm{dose} \mathrm{of} 100$ $\mathrm{mg} / \mathrm{kg}$ bw/day (Delclos et al., 2014)."

Proper cyclicity is considered essential to reach successful ovulation. An alteration of cyclicity may therefore directly induce at least subfertility through disturbed (delayed or absent) ovulation. The hormonal regulation of the cycle also influences the recruitment and maturation processes of the ovarian follicles. Different studies have linked modification of estrous cyclicity with impaired follicle dynamic. For example, Zaid et al. (2014) showed an increase of the occurrence of persistent diestrous (5/8 animals) in BPA-treated animals, jointly to an increase of the number of large antral-like follicles that did not reach ovulation, an increase of atretic cystic-like follicles and a decrease in the number of preantral follicles and corpus luteum. These data show that BPA alters the development of preovulatory follicles and their ovulation. Modifications in the length and/or hormonal environment of the different phases of the estrous cycle might likely impact the quality of oocytes and the quality of embryos. Therefore, the effect on cyclicity needs to be considered in relation to the alteration of fertility observed.

In humans there is several indications that estrous cycle disturbances are associated one way or the other to fertility issues. As synthetised by Kortenkamp et al. (2012), an association between menstrual cycle characteristics (e.g. length of the cycle, duration of menstrual bleeding) and sub-fecundity and spontaneous abortion has been observed in humans and menstrual patterns have been associated with chronic diseases, including breast and ovarian cancer, uterine fibroids, diabetes and cardiovascular disease. However, the causal link behind this association remains to be elucidated. Chronic anovulation is among the most common causes of female infertility. In women, shorter cycles are less likely to be followed by conception, and both shorter and longer cycles are more likely to be followed by spontaneous abortion. Cycles with up to 4 days menstrual bleeding had lower fecundity, and spontaneous abortion is less likely after cycles with more than 5 days of menstrual bleeding (Small et al., 2006). Alteration of cyclicity is therefore fully considered as an adverse effect in humans. 


\section{Endocrine disruption in relation to the alteration of the estrous cyclicity}

The specific pathways involved in the alteration of estrous cyclicity further to BPA exposure during development or in adulthood are very likely to be largely mediated through modifications of the hormonal regulation of the cycle, although with specificities depending on the period of exposure.

\subsection{Adult exposure}

\subsubsection{Background on the regulation of the estrous cycle in rodents}

It is well known that the estrous cycle is a process basically controlled by sequential endocrine/paracrine and autocrine regulations (Figure 1) (Richards, 2006). The key event is the endocrine dialogue between the hypothalamo-pituitary system and the ovarian follicles via the levels of estrogens that trigger the ovulatory surge of LH from the pituitary. The central event of this sequence is the positive feed back exerted by the estrogen surge occurring at the end of the follicular growth. At the end of the follicular growth, when plasma estrogens reach a threshold, they act positively on the hypothalamo-pituitary system to provoke the ovulatory peak of $\mathrm{LH}$ and FSH.

Aromatase is an enzyme responsible of the production of estradiol from testosterone. It is expressed in multiple organs such as gonads, placenta, brain, adipose tissue, blood vessels, skin, bones and uterine mucosa (Simpson et al., 1994). In the non-pregnant female, ovaries are by far the major source of circulating estrogens in vertebrates. Estrogen production results from a collaborative work inside the ovary: the thecainterstitial cells synthetise androgens from cholesterol and the granulosa cells, convert the androgens produced by theca-interstitial cells into estrogens as they specifically express cypP450arom (also called cyp19a1) encoding the aromatase, catalysing this conversion. Consequently, the proestrous rise in plasma estrogen concentrations is related to an increase in ovarian aromatase activity. The diestrus 1 , diestrous 2 and proestrus before $15 \mathrm{~h} 00$ correspond to the ovarian phase during which the pool of recruited preantral and antral follicles are growing and produce more and more estrogens.

From the beginning of diestrus 1 onwards, the follicles growth and estrogens production are stimulated by both FSH (stimulating granulosa cells) and LH (mainly stimulating theca-interstitial cells, and granulosa cells incidentally). Importantly, the preovulatory surge of estrogens is also largely due to the self-stimulation as the rise in estrogens further stimulates their own production (Figure 2). The estrogens stimulate follicle growth and protect the follicle from atresia, and consequently more and more cells produce estrogens. Furthermore, in theca-interstitial cells, estrogens act in a paracrine mode to up-regulate the stimulatory effect of LH on androgen production. Lastly, in granulosa cells, estrogens up-regulate in an autocrine fashion, via binding to ER $\beta$, the stimulatory effect of FSH and of LH on the expression of the cypP450arom. 


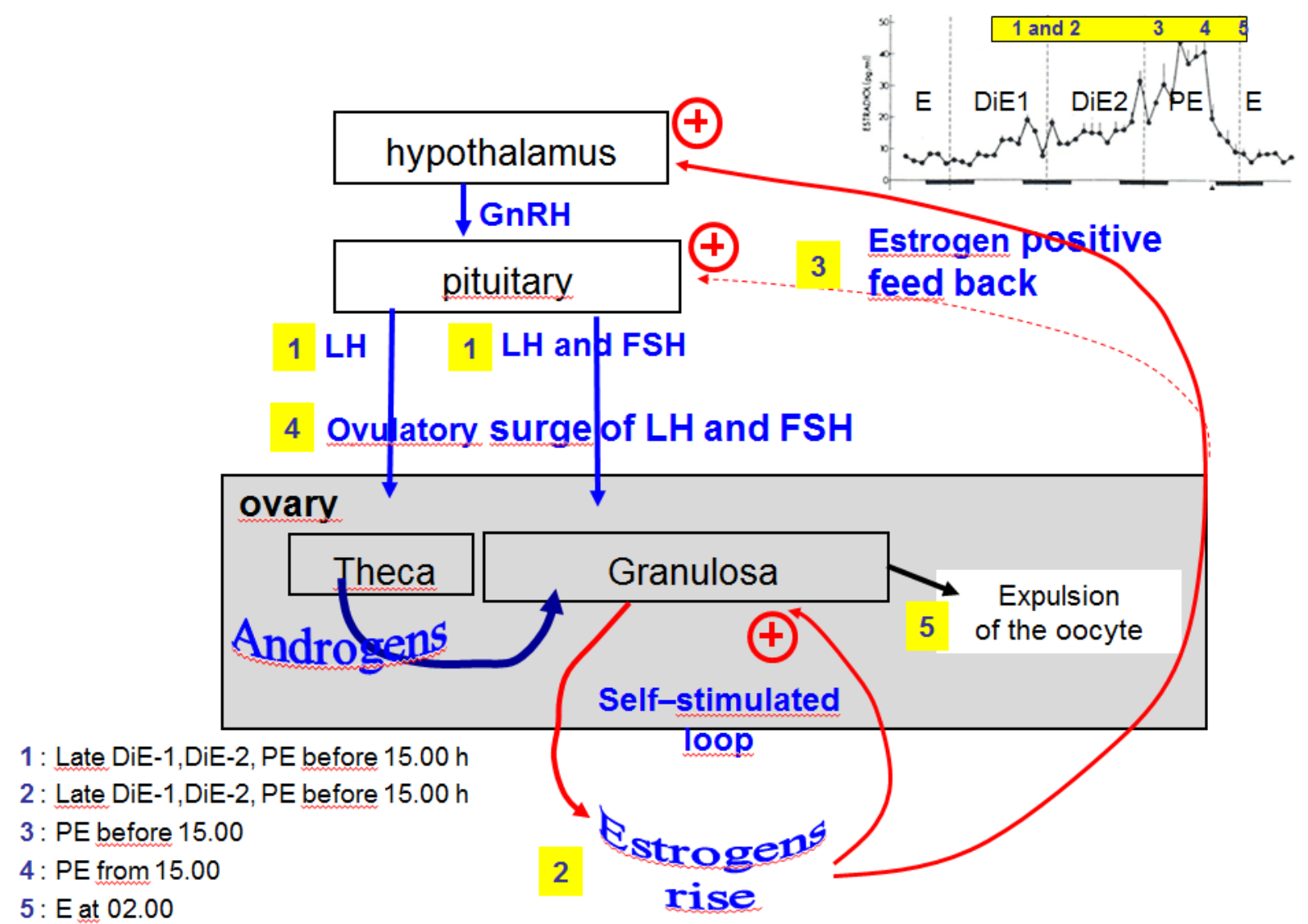

Figure 1: Temporal sequence of the main endocrine controls of the final follicle growth and ovulation in the rat

Step 1: From late Diestrus-1 (DiE-1) until proestrus (PE) $15 \mathrm{h00} \mathrm{LH}$ stimulates the production of androgens by theca cells and FSH (and incidentally LH) stimulates the conversion of these androgens into estrogens.

Step 2: Concomitantly, estrogens stimulate their own production via a self-stimulated loop detailed in Fig 2. Thus the estrogen production increases.

Step 3: High levels of estrogens act positively on the hypothalamo-hypophysis system and trigger a surge of LH and FSH from PE 15:00hrs (step 4) that induces ovulation at the estrous stage (step 5).

The side insert into fig 1 represents the level of estradiol-17ß in the peripheral plasma during the estrous cycle (from Smith et al., 1975).

The self-amplifying feedback mechanism of estrogens on their own production is mediated by intra-follicular factors. Among them, IGF-1 produced by theca-interstitial cells and granulosa cells plays an important role by enhancing the action of gonadotrophins. IGF-2, SF-1, BMP-15, GDF-9 and GATA4 are also involved. Lastly, in the granulosa cells of the preovulatory follicle, transcription factors such as PPAR- $\gamma$ inhibit CYP450arom transcription, whereas others such as LRH-1, SF-1, CREB and GATA4 activate this transcription. The ovary-specific proximal promoter II (PII) of CYP450arom contains response elements for these transcription factors. 


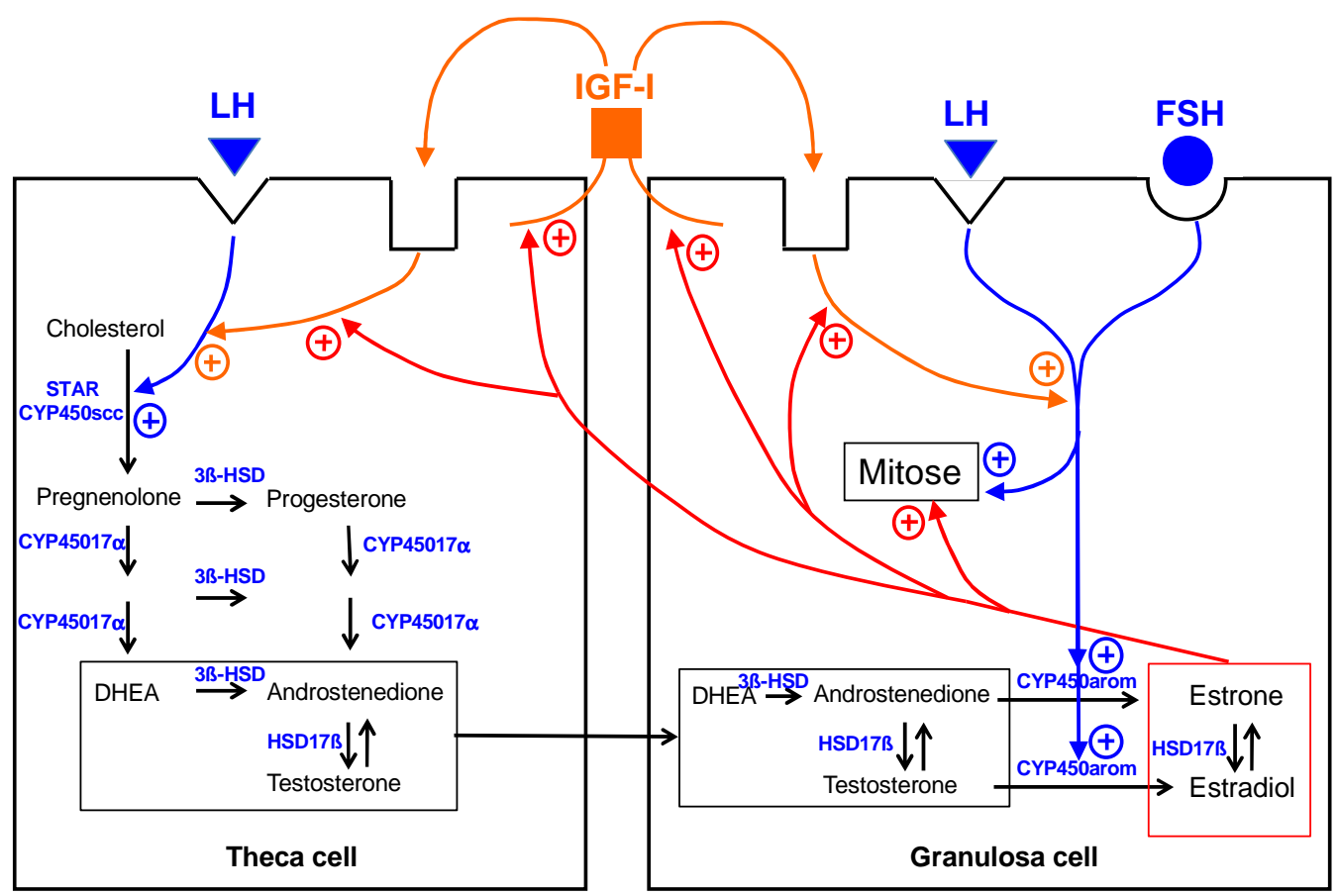

Figure 2: Main mechanisms of the self-stimulated estrogen synthesis in the preovulatory follicle. Estrogens (estrone and estradiol-17ß) stimulate the proliferation of the granulosa cells, and the secretion and action of IGF-I in the granulosa cells (autocrine action), and in thecal cells (paracrine action). In each cell type, IGF-I potentiates the positive effect of the gonadotrophins (LH in theca cells, and FSH (incidentally LH) in the granulosa cells) on specific steps in the steroid hormone biosynthetic pathway. STAR, steroid acute regulatory protein; CYP450scC : P450 cholesterol side chain cleavage enzyme (also named CYP11A1); CYP45017a: 17a-hydroxylase-17,20-desmolase (also named CYP17A1); CYP450arom : cytochrome P450 aromatase (also named CYP19A1); HSD3B: 3B-hydroxysteroid dehydrogenase; HSD17ß : 17ß-hydroxysteroid dehydrogenase; IGF-I : insulin-like growth factor I.

More precisely, the ovarian estradiol acts in the hypothalamic preoptic area to trigger $\mathrm{GnRH}$ liberation, which in turn stimulates LH increase in the pituitary (Figure 3). This gonadal feedback does not act directly on GnRH neurons but involves a neuronal cell type expressing kisspeptin. This hypothalamic neuropeptide coded by Kiss 1 gene acts upstream of $\mathrm{GnRH}$. Kisspeptin neurons located in the rostral periventricular area of the third ventricle (RP3V; including the anteroventral periventricular, caudal and rostral periventricular nuclei) of the preoptic area send projections to GnRH soma cells, which express the kisspeptin receptor (Kiss1R). Kisspeptin is a crucial regulator of the onset of puberty, sex hormone-mediated secretion of gonadotrophins, and control of fertility. During the proestrous phase, estradiol targets kisspeptin neurons, which express ER $\alpha$ and therefore integrate the positive signal of estradiol necessary to trigger the ovulatory surge of LH, through GnRH liberation. 


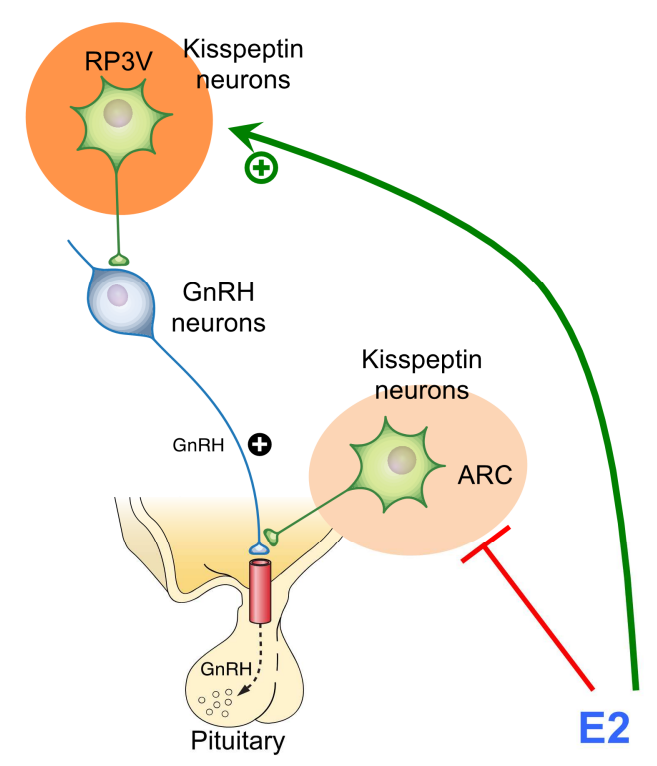

Figure 3. Kisspeptin neurons are located in two hypothalamic regions, the rostral periventricular area of the third ventricle (RP3V) and arcuate (ARC) nuclei. Kisspeptin neurons of the RP3V nucleus integrate the positive feedback (green arrow) exerted by estradiol $\left(E_{2}\right)$ to trigger the ovulatory surge of LH through GnRH liberation during the proestrous phase. The arcuate nucleus integrates the negative feedback (red line) exerted by estradiol during the other phases of the estrous cycle.

Furthermore, in rodents, the anteroventral periventricular nucleus (AVPV), where kisspeptin neurones are involved in the positive feedback of estradiol, receives afferent fibers from the suprachiasmatic nucleus. The circadian clock located in the latter nucleus coordinates and provides precise timing for the LH surge which starts at 15h00.

It may be noted that, in rodents, the ovulatory surge of LH triggers progesterone surge (peak following estradiol surge (Figure 1 ), which is required for female receptivity. During this stage, progesterone acts in hypothalamic areas through progesterone receptors, which are up-regulated by estradiol, thereby leading to the induction of female sexual behaviour.

In conclusion, the estrous cycle appears as a process basically controlled by sequential endocrine/paracrine and autocrine regulations. The key event is the endocrine dialogue between the hypothalamo-pituitary system and the ovarian follicles via the levels of estrogens that trigger the ovulatory surge of LH.

Importantly, this mechanism is common to all cycling mammals.

$$
\text { 4.1.2. }
$$

In vitro information indicative of endocrine activity of BPA

A number of in vitro studies show that BPA can alter the activity of ovarian cells. This is very likely to result in the disturbance of the estrous cycle, in particular when the steroidogenic activity of the ovaries is concerned (see above the biological process which controls the estrous cycle). The in vitro data are described below and summarised in Table 2.

Table 2: Summary of the in vitro studies showing an alteration of the ovarian steroidogenesis function likely to result in disturbance of estrous cyclicity if occurring in vivo.

\begin{tabular}{|l|l|l|l|l|l|}
\hline Cell type & Reference & Tissue & Concentration & Results & Conclusion \\
\hline
\end{tabular}




\begin{tabular}{|c|c|c|c|c|c|}
\hline \multirow{2}{*}{$\begin{array}{l}\text { Theca-interstitial } \\
\text { cells }\end{array}$} & $\begin{array}{l}\text { Peretz et al., } \\
2011\end{array}$ & $\begin{array}{l}\text { Mouse isolated antral } \\
\text { follicles }\end{array}$ & $\begin{array}{l}100 \text { and } 10 \mathrm{mg} / \mathrm{L} \\
(=440 \text { and } 44 \mu \mathrm{M}) \\
\text { BPA }\end{array}$ & $\begin{array}{l}\downarrow \text { Testo, } \downarrow \text { Androstenedione, } \\
\downarrow \text { DHEA-S, } \downarrow \text { STAR, } \\
\downarrow \text { CYP450scC, } \\
\rightarrow 3 \text { B-HSD, } \rightarrow \text { CYP450 } \\
17 \text { apha }\end{array}$ & \multirow{2}{*}{$\begin{array}{l}\text { No clear-cut } \\
\text { conclusion }\end{array}$} \\
\hline & $\begin{array}{l}\text { Zhou et al., } \\
2008\end{array}$ & $\begin{array}{l}\text { Theca-interstitial cells } \\
\text { isolated from immature } \\
\text { SD rats }\end{array}$ & 10 to $100 \mu \mathrm{M}$ BPA & $\uparrow \mathrm{STAR}, \uparrow$ CYP450scc & \\
\hline \multirow{6}{*}{ Granulosa cells } & $\begin{array}{l}\text { Zhou et al., } \\
2008\end{array}$ & $\begin{array}{l}\text { Granulosa cells isolated } \\
\text { from mature SD rats }\end{array}$ & 1 to $100 \mu \mathrm{M} \mathrm{BPA}$ & $\downarrow$ estradiol & \multirow{6}{*}{$\begin{array}{c}\text { BPA reduces } \\
\text { CYP450arom } \\
\text { expression } \\
\text { and } \\
\text { estrogen } \\
\text { production } \\
\text { in rodents, } \\
\text { domestic } \\
\text { animals and } \\
\text { human } \\
\text { granulosa } \\
\text { cells in all } \\
\text { studies. }\end{array}$} \\
\hline & $\begin{array}{l}\text { Peretz et al., } \\
2011\end{array}$ & $\begin{array}{l}\text { Mouse isolated antral } \\
\text { follicles }\end{array}$ & $\begin{array}{l}100 \text { and } 10 \mathrm{mg} / \mathrm{L} \\
(=440 \text { and } 44 \mu \mathrm{M}) \\
\text { BPA }\end{array}$ & $\downarrow$ estradiol & \\
\hline & $\begin{array}{l}\text { Mlynarcikova et } \\
\text { al., } 2005\end{array}$ & $\begin{array}{l}\text { Porcine granulosa cells } \\
\text { from antral follicles }\end{array}$ & 1 to $100 \mu \mathrm{M}$ BPA & $\downarrow$ FSH-induced estradiol & \\
\hline & $\begin{array}{l}\text { Watanabe et } \\
\text { al., } 2012\end{array}$ & $\begin{array}{l}\text { KGN (a human } \\
\text { granulosa-like cell line) }\end{array}$ & 5 to $100 \mu \mathrm{M} \mathrm{BPA}$ & $\downarrow$ CYP450arom & \\
\hline & $\begin{array}{l}\text { Kwintkiewicz et } \\
\text { al., } 2010\end{array}$ & $\begin{array}{l}\text { KGN and human } \\
\text { granulosa cells }\end{array}$ & 40 to $100 \mu \mathrm{M}$ BPA & $\begin{array}{l}\downarrow \text { FSH-induced } \\
\text { CYP450arom, } \\
\text { estradiol, } \\
\downarrow \text { IGF-I, } \downarrow \text { GATA-4, } \downarrow \text { SF-I, } \\
\uparrow \text { PPAR-gamma, }\end{array}$ & \\
\hline & $\begin{array}{l}\text { Mansur et al., } \\
2016\end{array}$ & Human granulosa cells & 8.8 to $88 \mu \mathrm{M}$ BPA & $\begin{array}{l}\downarrow \text { estradiol, } \downarrow \text { progesterone } \\
\downarrow \text { Cyp arom (mRNA and } \\
\text { protein) }\end{array}$ & \\
\hline
\end{tabular}

\subsubsection{Theca-interstitial cells}

Using isolated antral follicles from adult cycling female FVB mice, Peretz et al. (2011) observed dose-dependent and time-dependent reductions in estradiol-17ß, estrone, testosterone, androstenedione and DHEA-S synthesis after exposure to 100 and $10 \mathrm{mg} / \mathrm{L}$ (440 and $44 \mu \mathrm{M}$ ) BPA. Using addition of steroid substrates and reverse transcription polymerase chain reaction (RT-PCR) analyses, they demonstrated that BPA acts by reducing the activity and/or expression of STAR and CYP450scc, but not that of 3B-HSD and CYP45017- $\alpha$. Moreover, these effects of BPA are reversible once BPA is removed from the culture media (Peretz and Flaws, 2013).

In contrast, using theca-interstitial cells isolated from immature (30 days old) female Sprague-Dawley rats (previously daily injected with $1 \mathrm{mg} \mathrm{17ß-estradiol} \mathrm{from} 28$ to 30 days of age to stimulate ovarian development), Zhou et al. (2008) observed that BPA in the culture medium at high concentrations increases the expression of STAR (from 10 to $100 \mu \mathrm{M}$ i.e 2 to $23 \mu \mathrm{g} / \mathrm{mL}$ ) and CYP450scc (from 0.1 to $100 \mu \mathrm{M}$ i.e from 0.2 to 23 $\mu \mathrm{g} / \mathrm{mL})$.

These data indicated diverging results that could be explained by differences in the species used or because the animal the cells come from were on different maturity stage.

\subsubsection{Granulosa cells}

The effects of BPA have been investigated in rodent and porcine granulosa cells in several studies. Zhou et al. (2008) used a granulosa cells culture isolated from mature Sprague-Dawley rats and observed that an exposure range between 1 to $100 \mu \mathrm{M}$ BPA for $48 \mathrm{hrs}$ reduced the estradiol production and CYP450arom mRNA level in a dosedependent fashion. 
Peretz et al. (2011) showed that the mouse antral follicle cultured for 120 hours in the presence of $44 \mu \mathrm{M}$ BPA contained 4 times lower CYP450arom than the controls, but the difference was not statistically significant.

Mlynarcikova et al. (2005) reported that 1 to $100 \mu \mathrm{M}$ BPA inhibits FSH-induced estradiol$17 B$ synthesis in cultured granulosa cells isolated from antral porcine follicle.

Importantly the negative effect of BPA on aromatase expression and activity was also observed using human cells. Watanabe et al. (2012) used a KGN cells line (a human ovarian granulosa-like tumor cell line), and exposed them to BPA between 5 to $100 \mu \mathrm{M}$. They observed a dose-dependent reduction of the mRNA levels and activity of CYP450arom.

Kwintkiewicz et al. (2010) used KGN cell line, and exposed them to BPA in a range between 40-100 $\mu \mathrm{M}$. They observed a dose-dependent reduction of FSH-induced aromatase expression and estradiol secretion, and a reduction of the FSH-induced IGF-1 expression. mRNA levels of transcription factors SF-1 and GATA4 were decreased after BPA treatment. In contrast, both mRNA and protein levels of PPAR $\gamma$ were significantly upregulated by BPA in a dose-dependent manner and the authors suggests that the inhibitory effect of BPA on the expression of aromatase is mediated via PPAR $\gamma$ since overexpression of PPAR $\gamma$ in KGN cells also provokes a decrease in the expression of aromatase and IFG-1

Recently, Mansur et al. (2016) assessed the effects of BPA on a human granulosa cells culture obtained from patients undergoing IVF. The cells were exposed for 48 hrs to 8.8 $\mathrm{nM}, 88 \mathrm{nM}, 880 \mathrm{nM}, 8.8 \mu \mathrm{M}$ or at $88 \mu \mathrm{M}$ of BPA. The progesterone secretion was reduced for 8.8 and $88 \mu \mathrm{M}$ of BPA but not at lower doses. The highest BPA concentration showed a decrease of the estradiol production. The BPA at 8.8 and $88 \mu \mathrm{M}$ significantly reduced the mRNA levels of 3ß-HSD, CYP450scc and CYP450arom and at lower concentrations ( $8.8 \mathrm{nM}$ to $0.88 \mu \mathrm{M}$ ) no change was observed. The BPA exposures concentration did not affect the STAR and CYP17 $\alpha$ mRNA levels. Lastly, 3 $\beta$-HSD, CYP450scc and CYP450arom protein levels were reduced by $88 \mu \mathrm{M}$ of BPA.

\section{Note}

It can be noted that the inhibitory effect of BPA on the aromatase activity and/or expression was also observed in vitro in other cell types such as placental cells (Nativelle-Serpentini et al., 2003; Benachour et al., 2007; Huang \& Leung, 2009) and Leydig cells (Akingbemi et al., 2004).

\subsubsection{Summary and conclusion}

In conclusion, the in vitro effect of BPA on the theca-interstitial cells steroidogenesis seems to depend on the species, the maturity stage and/or the experimental procedure. In contrast, data dealing with the in vitro effect of BPA on the granulosa cells steroidogenesis are all converging to show that BPA reduces the estrogen production by this cell type by reducing the aromatase expression in all species studied including in humans. On granulosa cells, all the available data judged relevant for the assessment of the MoA are consistent and biologically concordant with the proposed MoA.

4.1.3. In vivo evidence with regard to an endocrine MoA

There are currently few data reporting in vivo effects of adult exposure to BPA together with investigation of the MoA. These studies are summarised in Table 3.

Table 3: in vivo evidence for endocrine mechanisms potentially underlying alteration of estrous cyclicity as a consequence of adult exposure to BPA 


\begin{tabular}{|c|c|c|c|c|}
\hline $\begin{array}{l}\text { Refe- } \\
\text { rence }\end{array}$ & $\begin{array}{c}\text { Species } \\
\text { Age }\end{array}$ & $\begin{array}{c}\text { Route (dose) } \\
\text { Duration }\end{array}$ & Effect & Evidence for ED MoA \\
\hline $\begin{array}{l}\text { Lee et al., } \\
2013\end{array}$ & $\begin{array}{l}\text { Rat SD } \\
\text { PND } 56\end{array}$ & $\begin{array}{l}\text { Gastric : } \\
\text { - BPA : } 1 \text { and } \\
100 \mu \mathrm{g} / \mathrm{kg} \mathrm{bw} / \mathrm{d} \\
-\mathrm{EB}: 1 \mu \mathrm{g} / \mathrm{kg} \\
\text { bw/d } \\
90 \text { days }\end{array}$ & $\begin{array}{l}\text { Disruption of } \\
\text { the estrous } \\
\text { cycle with } \\
\text { extended } \\
\text { estrous phase } \\
\text { of } 2-7 \text { days } \\
\text { with both BPA } \\
\text { doses and EB }\end{array}$ & $\begin{array}{l}\text { Both BPA doses and EB: } \\
\downarrow \text { plasma estradiol, } \downarrow \text { testosterone, } \\
\downarrow \text { STAR, } \\
\uparrow \text { apoptosis in follicles and corpus lutea. } \\
\rightarrow \text { FSH } \\
\text { Both BPA doses but not EB: } \\
\downarrow \text { aromatase in granulosa cells } \\
\downarrow \text { uterine estrogen-induced proteins (PCNA } \\
\text { calbindin-D9k) } \\
\downarrow \text { uterine collagens } \\
\uparrow \text { plasma and pituitary LH concentrations }\end{array}$ \\
\hline $\begin{array}{l}\text { Wang et } \\
\text { al., 2014b }\end{array}$ & $\begin{array}{l}\text { Mouse } \\
\text { ICR } \\
\text { Adult in } \\
\text { pro- } \\
\text { estrous }\end{array}$ & $\begin{array}{l}\text { Oral }(20 \mu \mathrm{g} / \mathrm{kg}) \\
\text { or ICV }(0,0.02, \\
0.2,2.0,20.0, \\
\text { and } 200.0 \mathrm{nM} / 3 \\
\mathrm{ml}) \\
\text { Single exposure } \\
\text { Analysis } 6 \text { hours } \\
\text { after exposure }\end{array}$ & $\begin{array}{l}\uparrow \text { GnRH and } \\
\text { Kiss } 1 \\
\text { expression } \\
\uparrow L H, \text { FSH, E }\end{array}$ & $\begin{array}{l}\text { Effects blocked by GPER and ER } \\
\text { antagonists } \\
\text { Estrous cyclicity not monitored but effects } \\
\text { very likely to be related to disruption of } \\
\text { estrous cyclicity }\end{array}$ \\
\hline $\begin{array}{l}\text { Kurian et } \\
\text { al., } 2015\end{array}$ & $\begin{array}{l}\text { Rhesus } \\
\text { monkey } \\
\text { Pubertal } \\
\text { female } \\
\text { (approx. } \\
38 \\
\text { months) }\end{array}$ & $\begin{array}{l}\text { Infusion of } 0 \text {, } \\
0.1,1 \text { or } 10 \mathrm{nM} \\
\text { BPA into stalk- } \\
\text { median eminence } \\
\text { of the } \\
\text { hypothalamus for } \\
240 \text { min } \\
\text { Simultaneous } \\
\text { collection of } \\
\text { dialysate }\end{array}$ & $\begin{array}{l}\downarrow \text { GnRH and } \\
\text { kisspeptin } \\
\text { release, } \uparrow \text { pulse } \\
\text { amplitude } \\
\text { interval at } 10 \\
\text { nM }\end{array}$ & Alteration of $\mathrm{GnRH}$ secretion \\
\hline
\end{tabular}

Lee et al. (2013) developed a key study using adult female Sprague-Dawley rats (PND 56) treated by oral gavage with 1 or $100 \mu \mathrm{g} / \mathrm{kg} /$ day of BPA for 90 days. Estradiol benzoate $(E B, 1 \mu \mathrm{g} / \mathrm{kg} /$ day) was used as positive control. Both BPA doses and EB lengthened the estrous phase, decreased plasma estradiol and testosterone concentrations, and increased apoptosis in follicle and corpus luteum. They decreased the protein levels of StAR but not those of P450SCC and 3B-HSD in theca-interstitial cells. The magnitude of these effects is important: plasma estradiol-17ß concentration was 2 times lower in rats treated by $1 \mu \mathrm{g} / \mathrm{kg} /$ day as compared with controls. No change in the levels of FSH in the plasma and the pituitary gland were observed. Both doses of BPA but not EB:

- decreased aromatase levels in the granulosa cells (with a stronger effect with 1 than with $100 \mu \mathrm{g} / \mathrm{kg} / \mathrm{d}$ BPA),

- decreased estrogen-induced proteins (PCNA calbindin-D9k) and collagen contents of the uterus,

- increased plasma LH concentration and pituitary LH content. The authors interpret this increase in LH levels as the following cascade: BPA primarily acts on the ovaries to reduce their estrogen production; this provokes a partial removal of the inhibitory negative feedback that is exerted by the circulating estrogens on the hypothalamo-pituitary system at this period of the estrous cycle, and, consequently, an increase in LH secretion.

This work is consistent with in vitro data described above. It shows that one clear-cut primary target of BPA in the ovary is the ovarian follicular cell and the control of aromatase gene expression. BPA first decreases estradiol levels by disturbing P450arom protein expression. Then, it is likely that the prolonged status of reduced estradiol subsequently provokes decreased feedback regulation of $\mathrm{LH}$, lengthening of the estrous cycle as well as ovarian cell apoptosis. 
Wang et al. (2014b) reported that exposure of adult female mice to BPA for 6 hours during proestrous, but not during estrous or diestrous, increases Kiss1 and GnRH mRNAs levels in the hypothalamic preoptic region as well as circulating levels of LH, FSH and estradiol. The assessment of LH surge showed an increased baseline before the LH surge, but no changes in the timing and level of this surge.

In a recent study, Kurian et al. (2015) using a microdialysis method, examined the effects of acute exposure to BPA $(0.1,1$, and $10 \mathrm{nM})$ directly infused to the stalk-median eminence on the release of $\mathrm{GnRH}$ and kisspeptin in mid to late pubertal ovarian intact female rhesus monkeys. They observed that the highest level of BPA exposure (10 nM i.e about $2 \mathrm{ng} / \mathrm{ml}$ which is a relevant concentration as far as human exposure is concerned) suppressed both $\mathrm{GnRH}$ and kisspeptin release since the first 20 minutes after exposure.

Although assessing BPA-induced effects at different periods of life (puberty vs adulthood) on different processes (kisspeptin and GnRH expression in body cells vs neuropeptide liberation at terminal nerves), these studies suggest that exposure to BPA could impair female reproductive function by directly influencing the hypothalamic neuroendocrine function.

Although the potential effects of such changes on the estrous cycle were not assessed due to the short time of exposure, the data presented are relevant for the proposed MoA. Indeed, these studies suggest that BPA can also affect the expression of two key neuropeptides involved in the ovulatory surge of LH process in rodents and non-human primates and that a neuroendocrine mechanism can also contribute to BPA-reprotoxicity (see detailed presentation of neuroendocrine regulation in the next sections). The literature search performed did not provide studies where those parameters would have been evaluated but not modified, although it is difficult to find negative results in general Itterature.

\subsubsection{Plausible link between adverse effects and endocrine MoA regarding adult exposure}

Convergent data explain how the effects of BPA on the ovary lead to alteration of the estrous cycle. BPA consistently reduces the conversion of androgens into estrogens in granulosa cells which triggers a sequential cascade resulting in a disturbance of the cycle (Figure 4). These results demonstrate a clear endocrine mode of action, namely the alteration of the ovarian steroidogenic activity, underlying estrous cycle disruption in adult rodents.

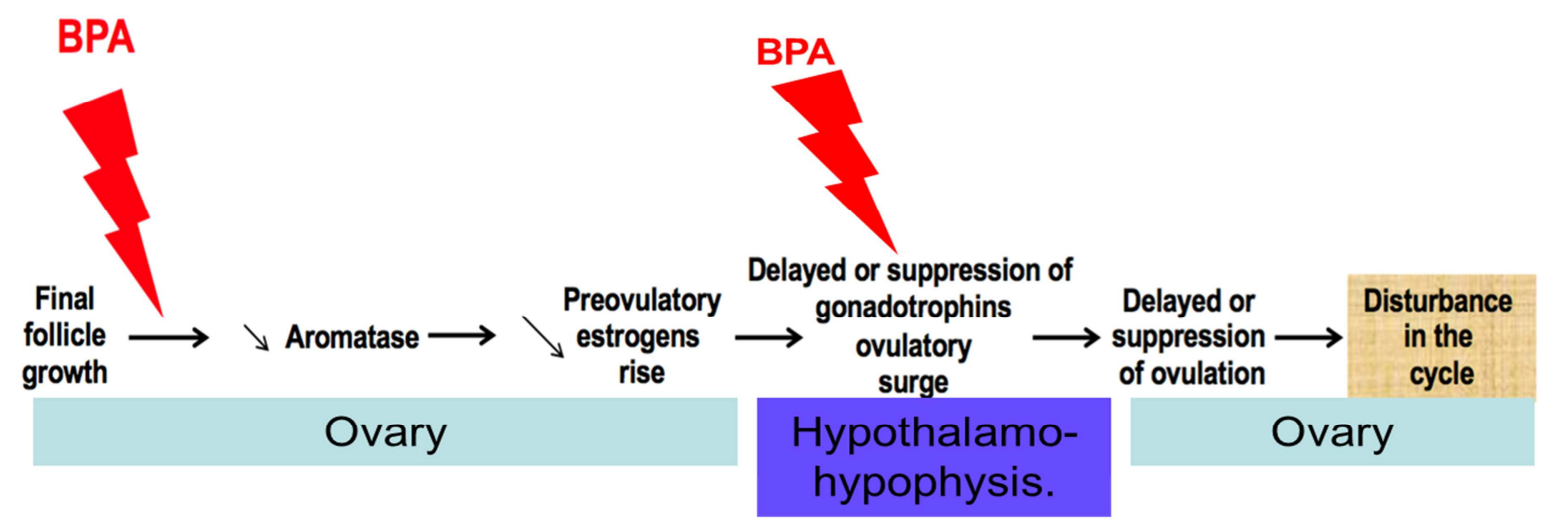

Figure 4 : Sequential cascade from the endocrine effect of BPA to its adverse effects.

A clearly demonstrated target of BPA is aromatase, in the preovulatory follicle. The BPA-induced reduction in the expression of this steroidogenic enzyme induces a reduction in the synthesis of estrogens. Thus, the preovulatory rise of estrogens is attenuated. Consequently, the estrogen- 
induced gonadotrophins ovulatory surge, is delayed or suppressed, and this induces disturbances in the cycle. Furthermore, BPA may act on the hypothalamo-hypophysis activity.

So far, there are indications of direct effects of BPA exposure during adulthood on the neuroendocrine system controlling the estrous cycle in rodents and non-human primates. However, it remains difficult to establish a clear link between the data on BPAinduced changes of this system and alterations of the estrous cycle based on the few data available. Indeed, although BPA-induced changes in the neuroendocrine expression of kisspeptin and GnRH were reported, data are far too limited to propose a succession of key events linking directly neuronal changes to ovarian cycle disruption in adult.

\subsection{Developmental exposure (in utero, perinatal, postnatal and/or prepubertal)}

Most of the studies related to developemental exposure were focused on the reproductive endocrine system

\subsection{1.}

Background on neuroendocrine fetal programming of estrous

cyclicity

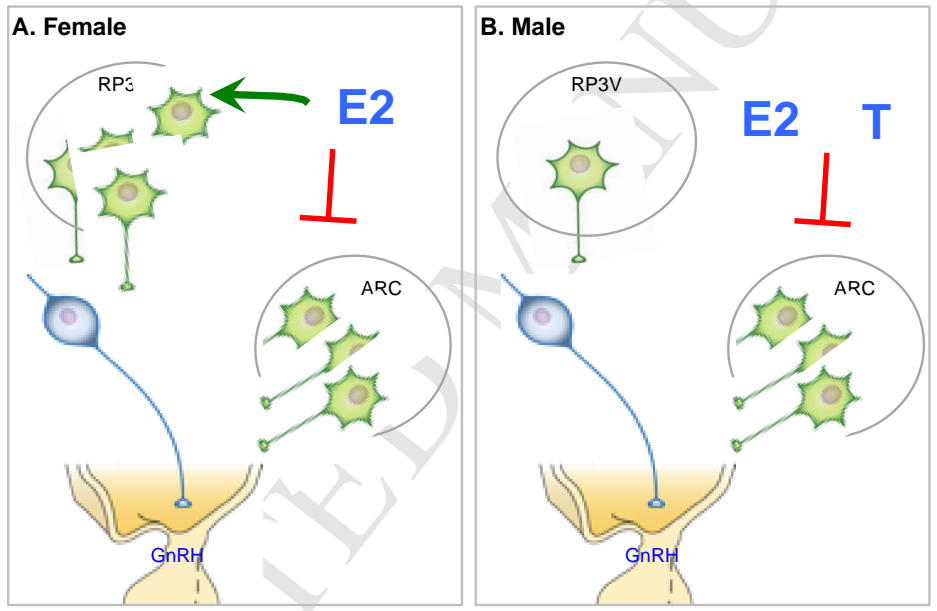

Figure 5. The neuroendocrine system involved in the control of the estrous cycle is regulated in a sexual dimorphic manner. Kisspeptin neurons located in the hypothalamic arcuate nucleus (ARC) integrate the negative feedback (red line) exerted by estradiol $\left(E_{2}\right)$ or testosterone (T) in both males and females. By contrast, kisspeptin neurons of the RP3V nucleus integrate the positive feedback (green arrow) exerted by estradiol in females. This positive regulation does not exist in males since the RP3V nucleus contains very few kisspeptin neurons in males by comparison to females.

The neuroendocrine pathways underlying the gonadotropic function are regulated by sex steroids in a sexually dimorphic manner (Figure 5). Indeed, the positive feedback exerted by estradiol to trigger $\mathrm{GnRH} / \mathrm{LH}$ preovulatory surge is specific to females. As developed above, ovarian estradiol exerts a positive control during the proestrous phase. It also exerts an inhibitory feedback during the other phases in females. In males, testosterone and its neural metabolite estradiol exert only a negative feedback. Both positive and negative feedback exerted by sex steroids involve kisspeptin neurons. Two hypothalamic neuronal populations of kisspeptin are differentially involved in the integration of these positive and negative signals. Kisspeptin neurons of the RP3V nucleus are targeted by estradiol during the proestrous phase in females, while kisspeptin cells of the hypothalamic ARC mediate the negative control of sex steroids in both males and females. Kisspeptin neurons of the ARC send also projections to GnRH 
neurons and co-express two neuropeptides neurokinin B and dynorphin, which are suggested to play also a role in the regulation of the gonadotropic axis.

At the neuroanatomical levels, the female RP3V contains more kisspeptin neurons by comparison to males. This sexual dimorphism is programmed as early as the perinatal period since testicular testosterone, and its neural metabolite estradiol, masculinize the male RP3V region (reviewed in Kauffman, 2009). In female rodents, brain regions are not impacted by sex steroids during this period since the ovaries are inactive and the neural structures involved in female reproduction are protected from maternal and sibling derived estradiol due to its selective binding to the $\alpha$-fetoprotein. Interestingly, BPA does not bind to the $\alpha$-fetoprotein (Milligan et al. 1998). At birth, the expression level of kisspeptin is low in the female RP3V. It increases progressively during the postnatal period under the control of ovarian estradiol. Indeed, the ovarian production of estrogens, which starts around postnatal day 7, promotes Kiss1 expression in this hypothalamic region. A maximal increase is observed during the prepubertal period and will be necessary for pubertal activation of $\mathrm{GnRH} / \mathrm{LH}$ axis and initiation of estrous cyclicity and female reproduction.

\subsubsection{In vitro information indicative of endocrine activity at the neuroendocrine level}

One in vitro study (Klenke et al., 2016) investigated the action of BPA on the neuroendocrine components of regulation of the estrous cycle and is summarised in Table 4. In this study, BPA reduces the frequency of oscillations in GnRH neurons from embryonic nasal explants collected after emergence of GnRH cells and other neuronal cell types from the plasma codes.

Table 4: Summary of the in vitro study showing an alteration of GnRH activity by BPA

\begin{tabular}{|l|l|l|l|l|}
\hline \multicolumn{1}{|c|}{ Reference } & \multicolumn{1}{|c|}{$\begin{array}{c}\text { Tissue and treatment } \\
\text { period }\end{array}$} & $\begin{array}{c}\text { Type of } \\
\text { evaluation }\end{array}$ & $\begin{array}{c}\text { Type of } \\
\text { modification }\end{array}$ & $\begin{array}{c}\text { Evidence for ED } \\
\text { MoA }\end{array}$ \\
\hline $\begin{array}{l}\text { Klenke et al., } \\
2016\end{array}$ & $\begin{array}{l}\text { Nasal explants from mice } \\
\text { embryos at embryonic day } \\
11.5 \text { (after emergence of } \\
\text { GnRH cells and other } \\
\text { neuronal cell types from the } \\
\text { plasma codes) used after } 6 \\
\text { days of culture }-50 \mu \mathrm{M}\end{array}$ & $\begin{array}{l}\text { Calcium } \\
\text { imaging }\end{array}$ & $\begin{array}{l}\text { BPA reduces the } \\
\text { frequency of } \\
\text { oscillations in } \\
\text { GnRH neurons }\end{array}$ & $\begin{array}{l}\text { Direct effect of BPA } \\
\text { on GnRH neurons }\end{array}$ \\
\hline
\end{tabular}

\subsubsection{In vivo evidence with regard to an endocrine MoA after} developmental exposure

As presented above, the perinatal and postnatal periods of exposure are sensitive to hormonal changes. Changes are required for the permanent programming of the female neuroendocrine system. Exposure to exogenous factors exhibiting hormone-mimetic activities such as BPA could then interfere with these processes and induce long-term effects on the integrity of the gonadotropic axis and the estrous cyclicity.

Several studies provide evidence of alteration of the estrous cycle as well as indications about the MoA. They are summarised below and in Table 5.

Table 5: Evidence for BPA-induced disturbance of estrous cyclicity in animal models and link with an endocrine disruptive MoA 


\begin{tabular}{|c|c|c|c|c|c|}
\hline Reference & $\begin{array}{l}\text { Species } \\
\text { Period }\end{array}$ & $\begin{array}{l}\text { Route } \\
\text { Doses }\end{array}$ & $\begin{array}{l}\text { Type of } \\
\text { evaluation }\end{array}$ & $\begin{array}{c}\text { Type of } \\
\text { modification }\end{array}$ & Evidence for ED MoA \\
\hline $\begin{array}{l}\text { Rubin et al., } \\
2001\end{array}$ & $\begin{array}{l}\text { Rat SD } \\
\text { GD6- } \\
\text { PND21 }\end{array}$ & $\begin{array}{l}\text { Oral (drinking } \\
\text { water) } \\
0.1-1.2 \mathrm{mg} / \mathrm{kg} / \mathrm{d}\end{array}$ & $\begin{array}{l}\text { Daily vaginal } \\
\text { cytology for } 18 \\
\text { consecutive days } \\
\text { at } 4 \text { and } 6 \text { months } \\
8 \text { female } \\
\text { offspring/ } \\
\text { group were } \\
\text { ovariectomised } \\
\text { and killed } 3 \\
\text { months later to } \\
\text { assess LH levels. }\end{array}$ & $\begin{array}{l}\downarrow \% \text { of animals with } \\
\text { regular estrous } \\
\text { cycle } \uparrow \text { duration of } \\
\text { the cycle and } \downarrow \text { nb } \\
\text { of estrous } \\
\text { cycles } / \text { animal with } \\
1.2 \mathrm{mg} / \mathrm{kg} / \mathrm{d}\end{array}$ & $\begin{array}{l}\downarrow \text { LH secretion in BPA- } \\
\text { treated OVX animals } \\
\text { showing a BPA-induced } \\
\text { alteration in the } \\
\text { endocrine function of } \\
\text { the hypothalomo- } \\
\text { pituitary gonadotropic } \\
\text { axis. But LH was not } \\
\text { evaluated in ovary } \\
\text { intact animals }\end{array}$ \\
\hline $\begin{array}{l}\text { Nikaido et al., } \\
2004\end{array}$ & $\begin{array}{l}\text { Mouse } \\
\text { CD1 } \\
\text { GD15- } \\
\text { GD19 }\end{array}$ & $\begin{array}{l}\text { Subcutaneous } \\
0.5-10 \mathrm{mg} / \mathrm{kg} / \mathrm{d}\end{array}$ & $\begin{array}{l}\text { Daily vaginal } \\
\text { smears between } 9 \\
\text { to } 11 \text { weeks }\end{array}$ & $\begin{array}{l}\uparrow m e a n \text { cycle length } \\
\uparrow \text { time in diestrus }\end{array}$ & $\begin{array}{l}\text { For diestrus: similar } \\
\text { increase with DES }\end{array}$ \\
\hline $\begin{array}{l}\text { Adewale et al., } \\
2009\end{array}$ & $\begin{array}{l}\text { Rat Long- } \\
\text { Evans } \\
\text { PND0- } \\
\text { PND3 }\end{array}$ & $\begin{array}{l}\text { Subcutaneous } \\
50-50000 \\
\mu \mathrm{g} / \mathrm{kg} / \mathrm{d} \\
\mathrm{sc}\end{array}$ & $\begin{array}{l}\text { Daily } 4 \text { days } \\
\text { vaginal lavage } \\
\text { from } 2 \text { weeks } \\
\text { after VO and } \\
\text { every two weeks } \\
\text { for } 13 \text { weeks }\end{array}$ & $\begin{array}{l}\text { Time and Dose- } \\
\text { dependent } \\
\text { decrease of the } \\
\text { number of cyclic } \\
\text { females }\end{array}$ & $\begin{array}{l}\text { Similar but more rapid } \\
\text { and more sustained } \\
\text { effect with PPT a } \\
\text { selective agonist of } \\
\text { ER } \alpha\end{array}$ \\
\hline $\begin{array}{l}\text { Fernández et } \\
\text { al., } 2009\end{array}$ & $\begin{array}{l}\text { Rat SD } \\
\text { PND1- } \\
\text { PND10 }\end{array}$ & $\begin{array}{l}\text { Subcutaneous } \\
\sim 5-50 \mathrm{mg} / \mathrm{kg} / \mathrm{d}\end{array}$ & PND90 & $\begin{array}{l}\text { Irregular estrus } \\
\text { cycles (persistent } \\
\text { estrus) }\end{array}$ & $\begin{array}{l}\downarrow \text { pituitary sensitivity to } \\
\text { GnRH in estrus in vivo } \\
\text { and in vitro } \\
\uparrow \text { GnRH pulse frequency } \\
\text { in juvenile and adults }\end{array}$ \\
\hline $\begin{array}{l}\text { Monje et al., } \\
2010\end{array}$ & $\begin{array}{l}\text { Rat } \\
\text { Wistar } \\
\text { PND1- } \\
\text { PND7 }\end{array}$ & $\begin{array}{l}\text { Subcutaneous } \\
0.5 \text { or } \\
20 \mathrm{mg} / \mathrm{kg} / \mathrm{d}\end{array}$ & $\begin{array}{l}\text { Daily vaginal } \\
\text { smears from } \\
\text { PND85 to PND } \\
100 \text { performed in } \\
\text { the group } \\
\text { exposed to } 0.05 \\
\mathrm{mg} / \mathrm{kg}\end{array}$ & $\begin{array}{l}\uparrow \text { time spent in } \\
\text { proestrus/ estrus } \\
\text { at } 0.05 \mathrm{mg} / \mathrm{kg} \text { (not } \\
\text { examined at } 20 \\
\mathrm{mg} / \mathrm{kg} \text { ) }\end{array}$ & $\begin{array}{l}\text { Females at } 20 \mathrm{mg} / \mathrm{kg} \\
\text { were incapable of } \\
\text { producing the LH } \\
\text { surge. } \\
\text { Alteration of GNRH } \\
\text { maturation process } \\
\text { and ER } \alpha \text { expression in } \\
\text { the AVPV and ARC, } \\
\text { and PR in the AVPV }\end{array}$ \\
\hline $\begin{array}{l}\text { Delclos et al., } \\
2014\end{array}$ & $\begin{array}{l}\text { Rat SD } \\
\text { From GD6 }\end{array}$ & $\begin{array}{l}\quad \begin{array}{l}\text { Oral } \\
\text { (gavage) }\end{array} \\
2.5,8,25,80 \\
260,840,2700 \\
100000,300000 \\
\mu \mathrm{g} / \mathrm{kg} / \mathrm{d}\end{array}$ & $\begin{array}{l}\text { Daily vaginal } \\
\text { cytology from } \\
\text { PND } 69 \text { to } 90 \text { and } \\
\text { from PND } 150 \text { to } \\
170\end{array}$ & $\begin{array}{l}\uparrow \% \text { female with } \\
\text { extended estrus } \\
\text { (highest dose only) }\end{array}$ & $\begin{array}{l}E E_{2} \text {-like effect } \\
\uparrow E_{2} \text { and } P R L- \\
\downarrow \text { progesterone }\end{array}$ \\
\hline $\begin{array}{l}\text { Wang et al., } \\
2014 a\end{array}$ & $\begin{array}{l}\text { Mouse } \\
\text { FVB } \\
\text { GD11- } \\
\text { PND0 }\end{array}$ & $\begin{array}{l}\text { Oral (gavage) } \\
0.5-20-50 \\
\mu \mathrm{g} / \mathrm{kg} / \mathrm{d}\end{array}$ & $\begin{array}{l}\text { From PND21-51 } \\
\text { Daily Vaginal } \\
\text { smears }\end{array}$ & $\begin{array}{l}0.5 \mu \mathrm{g} / \mathrm{kg} / \mathrm{d} \\
\downarrow p o e s t r u s \text { and } \\
\text { estrus } \uparrow \text { metestrus } \\
20 \mu \mathrm{g} / \mathrm{kg} . \mathrm{d}: \searrow \\
\text { estrus } \\
\text { Not with high dose } \\
50 \mu \mathrm{g} / \mathrm{kg} / \mathrm{d}\end{array}$ & $\begin{array}{l}\text { For proestrus and } \\
\text { metestrus: idem DES }\end{array}$ \\
\hline
\end{tabular}

In the study from Wang et al. (2014a), effects on estrous cyclicity were observed at low doses. However, the only evidence that these alterations might be due to endocrinemediated mechanisms arises from the observation that part, but not all, of these effects are reproduced in the diethylstilbestrol (DES) positive controls. In the study from Delclos et al. (2014) issued from CLARITY-BPA, a Consortium Linking Academic and Regulatory Insights on BPA Toxicity), an unprecedented collaboration that brings together academic 
researchers with federal regulators (NIEHS and National Toxicology Program (NTP)) to answer critical research questions about BPA that will help inform regulatory decisionmaking (Heindel et al., 2015), effects on estrous cyclicity were conclusive in the highest dose group after periconceptional and all life-long exposure. This effect was seen in the positive $\mathrm{EE}_{2}$-treated animals as well. In addition, the similarity of effects between BPA and positive estrogenic controls or ERa antagonist was also observed in Nikaido et al. (2004) or Adewale et al. (2009), respectively.This shows that BPA displays an estrogenlike effect.

In another study (Rubin et al., 2001), results in some female offspring exposed perinatally to the highest dose of BPA $(1.2 \mathrm{mg} / \mathrm{kg} \mathrm{bw} / \mathrm{d})$ revealed intermittent extended periods of diestrus, whereas other females exhibited extended periods of proestrus and/or estrus. Beside altered patterns of estrous cycle in approximately $80 \%$ of 4 -month and 6-month old females, the offsprings of the high-dose BPA dams also revealed decreased levels of plasma luteinizing hormone (LH) $(-18 \%)$ in adulthood after ovariectomy. Decreased LH secretion in BPA-treated ovariectomised animals showed an alteration of the endocrine function of the hypothalomo-pituitary gonadotropic axis. However, it should be noted that LH was not evaluated in ovary -intact animals, thus direct correlation between LH secretion alteration and the estrous cycle disturbances could not be made.

More convincing evidence toward involvement of hormonal disruption was provided by the concomitant observation of estrous cycle disturbance together with modification of LH and/or GnRH release (Monje et al., 2010; Fernández et al., 2009).

Finally, one additional study provides relevant indications of a potential disruption of the estrous cycle hormonal regulation. In the study from Veiga-Lopez et al. (2014), sheep were exposed to BPA during gestation from GD30 to GD90 at doses of $0.05-0.5$ or 5 $\mathrm{mg} / \mathrm{kg} / \mathrm{d}$. This exposure was not associated with major alterations of the amplitude and/or the timing of the estradiol and LH surges during the preovulatory phase of the estrous cycle. However, the time interval between estradiol and LH peaks appeared to be decreased in BPA-exposed animals as compared to vehicle ones. The impact of such modifications on the overall estrous cycle was not determined in this study. Several other studies in sheep indicate that BPA developmental exposure (either in utero or neonatally) can alter the follicle dynamic (Rivera et al., 2011; Veiga-Lopez et al., 2014) or the ovarian response to FSH (follicular growth, $\mathrm{FSH}$-induced estradiol secretion) in prepubertal animals (Rivera et al., 2015).

At the neuroendocrine level, ten studies addressed the effects of developmental exposure to BPA on kisspeptin and GnRH expression or liberation (Table 6), with half of them investigating estrous cyclicity as well. Regardless of this latter parameter, 8/10 studies report changes in kisspeptin and/or GnRH expression and liberation, suggesting a potential long-term effect of BPA exposure. The limited number of studies and differences in doses and analyses do not allow concluding whether developmental exposure to BPA inhibits or increases neuropeptide expression. It seems, however, that neonatal and early postnatal exposure diminishes, while a longer exposure time starting from gestation until weaning increases, kisspeptin expression.

Table 6: Studies addressing the effects of developmental exposure to BPA on the kisspeptin/GnRH system

\begin{tabular}{|c|c|c|c|c|c|}
\hline Reference & $\begin{array}{l}\text { Animal } \\
\text { model }\end{array}$ & $\begin{array}{l}\text { Doses } \\
\text { (route) }\end{array}$ & Period & Effects on Kisspeptin & Effects on GnRH \\
\hline $\begin{array}{l}\text { Adewale et } \\
\text { al. (2009) }\end{array}$ & $\begin{array}{l}\text { Long } \\
\text { Evans } \\
\text { rats }\end{array}$ & $\begin{array}{l}50 \mu \mathrm{g} / \mathrm{kg}- \\
50 \mathrm{mg} / \mathrm{kg} \\
(\mathrm{SC})\end{array}$ & $\begin{array}{l}\text { PND0- } \\
\text { PND3 }\end{array}$ & & $\begin{array}{l}\text { No modifcation in GnRH } \\
\text { expression in the OVLT }\end{array}$ \\
\hline
\end{tabular}




\begin{tabular}{|c|c|c|c|c|c|}
\hline $\begin{array}{l}\text { Fernández } \\
\text { et al. } \\
\text { (2009) }\end{array}$ & $\begin{array}{l}\text { Sprague- } \\
\text { Dawley } \\
\text { rats }\end{array}$ & $\begin{array}{l}50 \mu \mathrm{g} / 50 \mu \mathrm{L} \\
- \\
500 \mu \mathrm{g} / 50 \mu \mathrm{l} \\
(\mathrm{SC})\end{array}$ & $\begin{array}{l}\text { PND1- } \\
\text { PND10 }\end{array}$ & & $\begin{array}{l}\text { Increased infantile GnRH } \\
\text { pulsatility. During } \\
\text { adulthood, diminished } \\
\text { GnRH-induced secretion of } \\
\text { LH and disturbed } \\
\text { pulsatility }\end{array}$ \\
\hline $\begin{array}{l}\text { Navarro et } \\
\text { al. (2009) }\end{array}$ & $\begin{array}{l}\text { Wistar } \\
\text { rats }\end{array}$ & $\begin{array}{l}100- \\
500 \mu \mathrm{g} / \mathrm{rat} \\
(\mathrm{SC})\end{array}$ & $\begin{array}{l}\text { PND1- } \\
\text { PND5 }\end{array}$ & $\begin{array}{l}\text { Diminished Kiss-1 mRNAs levels } \\
\text { in the hypothalamus at PND30 }\end{array}$ & \\
\hline $\begin{array}{l}\text { Patisaul et } \\
\text { al. (2009) }\end{array}$ & $\begin{array}{l}\text { Long } \\
\text { Evans } \\
\text { rats }\end{array}$ & $\begin{array}{l}50 \mu \mathrm{g} / \mathrm{kg}- \\
50 \mathrm{mg} / \mathrm{kg} \\
(\mathrm{SC})\end{array}$ & $\begin{array}{l}\text { PND1- } \\
\text { PND4 }\end{array}$ & $\begin{array}{l}\text { No effect of BPA exposure in the } \\
\text { AVPV, decrease in the ARC at } \\
\text { the higher dose. Diminished } \\
\text { kisspeptin cell density in the } \\
\text { AVPV and ARC by with ERa } \\
\text { agonist. }\end{array}$ & \\
\hline $\begin{array}{l}\text { Monje et } \\
\text { al. (2010) }\end{array}$ & $\begin{array}{l}\text { Wistar } \\
\text { rats }\end{array}$ & $\begin{array}{l}0.05,20 \\
\mathrm{mg} / \mathrm{kg} \\
(\mathrm{SC})\end{array}$ & $\begin{array}{l}\text { PND1- } \\
\text { PND7 }\end{array}$ & & $\begin{array}{l}\text { mRNAs GnRH increased at } \\
\text { BPA-0.05 } \\
\text { mRNAs GnRH decreased } \\
\text { at BPA-20 }\end{array}$ \\
\hline $\begin{array}{l}\text { Xi et al. } \\
(2011)\end{array}$ & $\begin{array}{l}\text { CD1- } \\
\text { mice }\end{array}$ & $\begin{array}{l}12-25- \\
50 \mathrm{mg} / \mathrm{kg} \\
\text { (oral) }\end{array}$ & $\begin{array}{l}\text { G1-PND49 } \\
\text { or PND21- } \\
\text { PND49 }\end{array}$ & $\begin{array}{l}\text { G1-PND49: Increased } \\
\text { Kiss1mRNA expression in the } \\
\text { hypothalamus at BPA- } 25 \text { and } \\
50\end{array}$ & $\begin{array}{l}\text { G1-PND49: increased } \\
\text { GnRH expression levels in } \\
\text { the hypothalamus at BPA- } \\
25 \text { and } 50 \text {. No } \\
\text { modification in GnRH-R } \\
\text { expression levels in the } \\
\text { pituitary }\end{array}$ \\
\hline $\begin{array}{l}\text { Cao et al. } \\
(2012)\end{array}$ & $\begin{array}{l}\text { Long- } \\
\text { Evans } \\
\text { rats }\end{array}$ & $\begin{array}{l}50 \mu \mathrm{g} / \mathrm{kg}- \\
50 \mathrm{mg} / \mathrm{kg} \\
(\mathrm{SC})\end{array}$ & $\begin{array}{l}\text { PND0- } \\
\text { PND2 }\end{array}$ & $\begin{array}{l}\text { Diminished Kiss } 1 \text { expression } \\
\text { ( } m \text { RNAs) in the RP } 3 \mathrm{~V} \text { at PND } 10 . \\
\text { No modification of Kiss } 1 \text { in the } \\
\text { ARC }\end{array}$ & \\
\hline $\begin{array}{l}\text { Losa-Ward } \\
\text { et al. } \\
\text { (2012) }\end{array}$ & $\begin{array}{l}\text { Wistar } \\
\text { rats }\end{array}$ & $\begin{array}{l}50 \mu \mathrm{g} / \mathrm{kg}- \\
50 \mathrm{mg} / \mathrm{kg} \\
(\mathrm{SC})\end{array}$ & $\begin{array}{l}\text { PND0- } \\
\text { PND3 }\end{array}$ & $\begin{array}{l}\text { No differences in kisspeptin cell } \\
\text { density in the AVPV or } \\
\text { kisspeptin-GnRH appositions. } \\
\text { Diminished cell density and } \\
\text { number of RFRP3 neurones, and } \\
\text { RFRP3-GnRH appositions }\end{array}$ & \\
\hline $\begin{array}{l}\text { Naulé et } \\
\text { al. (2014) }\end{array}$ & $\begin{array}{l}\text { C57BL6] } \\
\text { mice }\end{array}$ & $\begin{array}{l}0,05-5 \\
\mathrm{mg} / \mathrm{kg} / \mathrm{d} \\
\text { (oral) }\end{array}$ & $\begin{array}{l}\text { GD15- } \\
\text { PND21 }\end{array}$ & $\begin{array}{l}\text { Increased kisspeptin number in } \\
\text { the RP3V } \\
\text { of adult females }\end{array}$ & \\
\hline $\begin{array}{l}\text { Franssen } \\
\text { et al. } \\
(2016)\end{array}$ & $\begin{array}{l}\text { Wistar } \\
\text { rat }\end{array}$ & $\begin{array}{l}25 \mathrm{ng}, 25 \\
\mathrm{mg}, 5 \\
\mathrm{mg} / \mathrm{kg} / \mathrm{d} \\
(\mathrm{SC})\end{array}$ & $\begin{array}{l}\text { PND1- } \\
\text { PND15 }\end{array}$ & & $\begin{array}{l}\text { GnRH IPI increased by } 25 \\
\text { ng, reduced by } 5 \mathrm{mg}\end{array}$ \\
\hline
\end{tabular}

Recent neuroanatomical studies described modifications in the expression levels of estrogen receptors in brain areas underlying female reproduction, such as the preoptic area and AVPV subregion or the mediobasal hypothalamus and ARC, following developmental exposure to BPA (Monje et al., 2009; Monje et al., 2010; Rebuli et al., 2014; Cao et al., 2014; Yu et al., 2015). These data clearly indicate that developmental exposure to BPA can be associated in animal models with an altered development of the neuroendocrine component of the gonadal axis. From a physiological point of view, it is legitimate to assume that most of these alterations can possibly lead to disruption of estrous cyclicity later in life. However, the majority of these studies did not monitor cyclicity, which precludes any definitive conclusion regarding a potential functional link between these developmental neuroendocrine alterations and perturbation of estrous cyclicity in adults.

\subsubsection{Plausible link between adverse effects and endocrine MoA regarding developmental exposure}

Not all studies provide clear indications of a direct link between a disruption of estrous cyclicity due to BPA exposure and endocrine or neuroendocrine mechanisms. The delay between the expression of the neuroendocrine mode of action evidenced during developmental stages (evaluation of tissue expression of genes/ proteins such as 
kisspeptin) and the effect on estrous cyclicity that can be evidenced only in fully mature animals render their observation within the same study/animal almost impossible. Nevertheless, many studies show that the basic (neuro) endocrine mechanisms implicated in the finely tuned regulation of the gonadotropic function underlying the estrous cycle can be altered in response to BPA exposure, in particular after developmental exposure. BPA has been shown to affect the hypothalamic expression of kisspeptin, a key neuropeptide in the regulation of the HPG axis to later achieve the release of hormones at the appropriate time and concentrations during the cycle. In particular, studies by Monje et al. (2010) and Fernández et al. (2009) provide a link between neuroendocrine changes and alteration of the cycles through concomitant observation of an alteration of hormones of the HPG axis and a cycle disturbance. In addition, the affected targets are similar to a large extent to targets affected by either estrogen agonist or estrogenic positive controls. Thus, animal and in vitro data support the hypothesis of an endocrine-related MoA of BPA to induce perturbation of estrous cyclicity after developmental exposure.

It is noteworthy however, that based on available data, it is sometimes difficult to state whether those endocrine alterations are the primary mode of action or just consequences of a non-endocrine related mechanism such as meiotic alteration or epigenetic modifications within the oocytes and/or other follicular cell types. This is typical of the regulatory loop systems that are the basis of endocrinology. As long as an endocrine-related modification can be evidenced for at least one step of these regulatory loops, it can be considered that the substance is acting as an endocrine disruptor.

\section{Human relevance}

Most of the evidence comes from rodent studies. Peculiarities of the reproductive physiology in those species as potential sources of uncertainties on the relevance of the results for humans are discussed hereafter together with commonalities across species.

\subsection{Circadian synchronisation of estrous cycle is specific for rodents}

The preovulatory LH surge, which characterises the proestrus depends on neural hypothalamic signals tightly coupled to the $24 \mathrm{hrs}$ light-dark cycle in rodents. The disruption of this signal, through pentobarbital administration during mid-proestrus for example, leads to a delayed ovulation by exactly 24 hours. In rat, the synchronisation of the estrous cycle is related to the expression of an endogenous circadian rhythm. In women, the spontaneous initiation of the preovulatory LH surge generally occurs in the morning in association with high cortisol levels, suggesting a role for the hypothalamus in timing human ovulation. However, the most recent evidence suggests that this neural component of the control system timing the LH surge in women translates diurnal changes in environmental cues rather than an endogenous circadian rhythm. It appears therefore that in rodents, the modification of the duration of the different phases of the estrous cycle might in some cases reflect disruption of the circadian synchronisation of the $\mathrm{GnRH} / \mathrm{LH}$ preovulatory surge and that this is likely not the case in humans.

The picture is quite different when the observed parameter is the percentage of females exhibiting regular estrous cycles. This type of modification is more likely to signal a profound alteration of the basic mechanisms underlying the cross talk between the ovaries, the pituitary and the brain, which are well preserved among animal species.

Overall, there is therefore some degree of uncertainty regarding the relevance to humans of rodent data on the estrous cycle disturbances when they relate to the duration of each phase of the cycle. However, when the results are expressed in terms of percentage of females exhibiting irregular estrous cycles as seen in several studies with BPA it is very likely that these effects can be considered as relevant to humans. In addition, alterations of the ovarian steroidogenic activity and/or of the neuroendocrine 
pathways mediating sexual steroid feedback are evidenced with BPA and provide support for human relevance since these are basic mechanisms underlying the estrous cycle that are common to most mammal species.

\subsection{Differences in the timing of the ontogeny of the neuroendocrine axis and/or the gonads}

The sequential events and regulations during development of the gonads and neuroendocrine reproductive axis is common to all mammals including human. However, the duration of each period is highly variable as shown in Figure 6, Thus, as an example, an exposure to BPA at birth will act on ovaries at different degrees of maturation in rodents (meiosis prophase period) and in humans (meiosis prophase arrested).

In addition, in rodents, unlike in some other mammals (rabbit, sheep, human), estrogen production by the ovary starts after birth consistently with a very low aromatase expression in the ovary during fetal life (Picon et al., 1985; Greco \& Payne, 1994; Daniel-Carlier et al., 2013; Payen et al., 1996; Fowler et al., 2011). Assuming that like in adult, BPA can alter early steroidogenesis during development, it can be hypothesized that species exhibiting steroidogenic activity in utero could be more sensitive than rodents to the effects of BPA fetal exposure. This might be a plausible explanation for the fact that in the rodent studies, the effect of BPA was the most obvious following postnatal exposure i.e at a period when the offspring steroidogenesis occurs. From this point of view, the effect of prenatal exposure to BPA on estrous cycle proceeding from altered gonad differentiation and/or folliculogenesis might be underestimated in humans when evaluated through rodent data. The effects of ovarian development alterations (observed after culling) on disruption of the estrous cycle in adults cannot be simultaneously evaluated in the same animals.

Overall, although the critical periods of exposure may differ in humans, it does not affect the general relevance of the effect/MoA. 

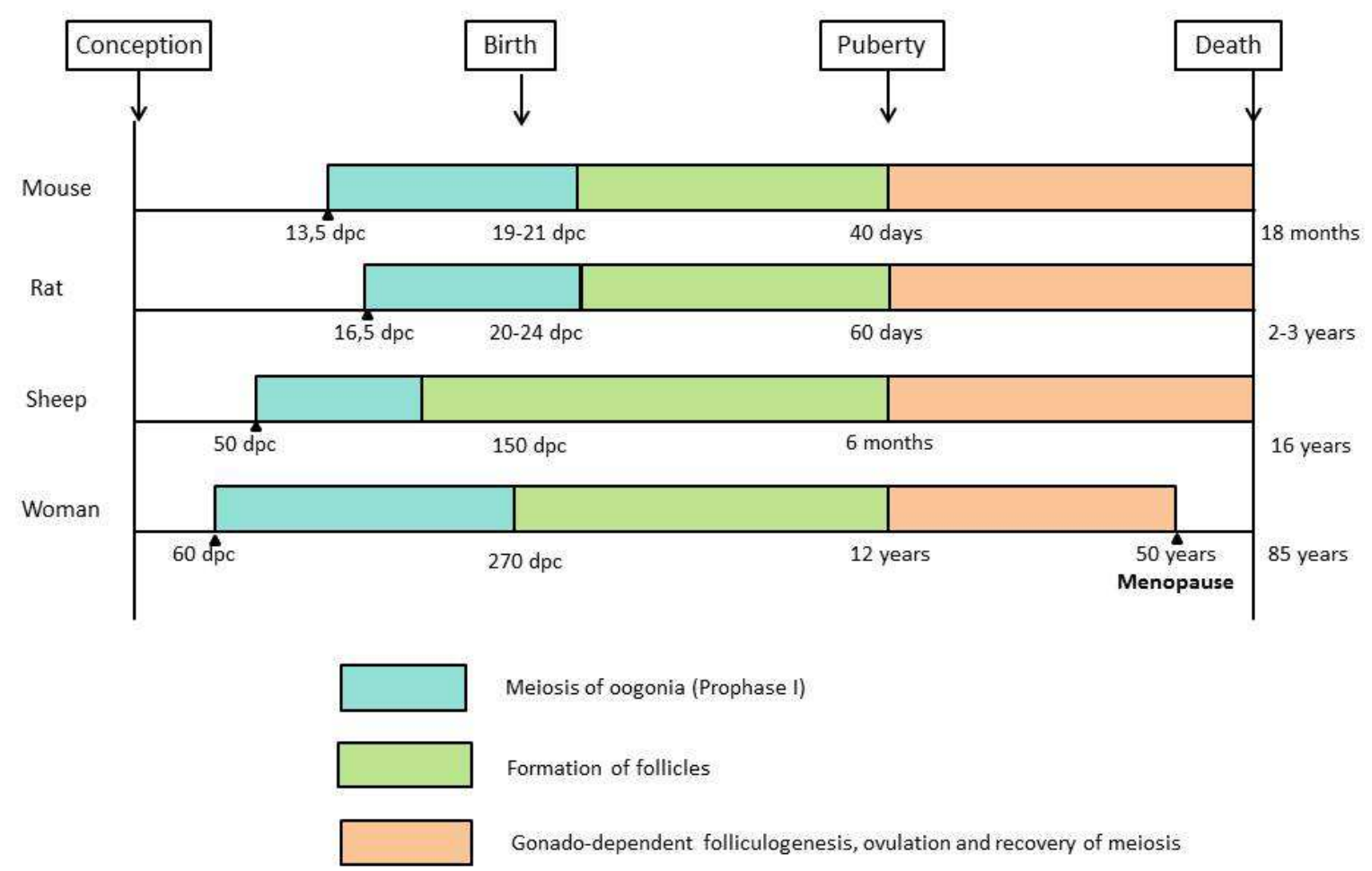

Meiosis of oogonia (Prophase I)

Formation of follicles

Gonado-dependent folliculogenesis, ovulation and recovery of meiosis

dpc: days post-conception

Figure 6 : Ontogeny of the ovarian function in different species of mammals.

5.3. Differences and commonalities in the endocrine and neuroendocrine control of the ovarian cycle in adults

\subsubsection{Ovarian control of the ovarian cycle}

The cycle in humans differs from that in rat and mice in its duration (28 days on average), in a clear separation between follicular and lutea phases, and in a uterine cycle characterised by menstruations.

Furthermore, as explained here above, the follicular phase of the estrous cycle in rodents is characterised by a peak of progesterone induced by the ovulatory surge of LH since the corpus lutea of the previous cycle is still functional at this time in rodents. This peak of progesterone does not impact the running of the cycle and is important to synchronise ovulation and female receptivity to male mounting in rodents. Indeed, liberated progesterone induces female receptivity, which is restricted to this period. This peak of progesterone does not occur in women, since progesterone is secreted during the luteal phase of the estral cycle only.

Furthermore, in humans there is a larger variability in the duration of the cycle from one cycle to another in the same woman and from one woman to another. It results from variability in the duration of the terminal growth of the follicle, leading to variability in the delay to reach the estrogens threshold that will trigger the pituitary gonadotrophins surge. Thus, the duration of the follicular phase is variable. Conversely, the duration of the luteal phase is relatively constant.

Another difference is the control of the corpus luteum regression, which is exerted by the corpus lutea themselves in primates and by the uterus in rodents, but both mechanisms 
involve the same ultimate hormonal control through PGF2 $\alpha$.

In conclusion, there are some differences in the endocrine control of the cycle between rodents and humans. Nervertheless, the key regulatory endocrine mechanisms of the cycle are the same. Importantly, in all cycling mammalian species including primates, it is the progressive increase in estrogens secretion at the end of the follicular phase that triggers the release of $\mathrm{LH}$ and $\mathrm{FSH}$ ovulatory surges. In all cycling species, the experimental suppression of the production or the action of estrogens during the end of the follicular growing phase suppresses the ovulatory peak of gonadotrophins. Consequently, the BPA-induced reduction of the aromatase expression in the follicle described above is expected to trigger disturbances in the menstrual cycle in humans as well as alteration of estrous cycle in rodents.

\subsubsection{Neuroendocrine control in humans}

In humans, the importance of kisspeptin was first demonstrated by the hypogonadotropic hypogonadism of patients carrying a mutation of the KISS1R (de Roux et al., 2003; Seminara et al., 2003). More recent studies show that kisspeptin acts also upstream of $\mathrm{GnRH}$ neurones to coordinate $\mathrm{GnRH}$ and LH pulsatility (reviewed in Skorupskaite et al., 2014). It stimulates the secretion of both LH and FSH, with a preferential stimulation of the former. Kisspeptin has also been shown to mediate both negative and positive feedback of sex steroids. In women, it seems therefore that sex steroid feedback involves both the hypothalamus and the pituitary gland.

At the neuroanatomical level, kisspeptin neurones extend from the preoptic area through to the infundibular nucleus (homologous to the ARC in rodents), as for GnRH neurones. In the infundibular region, kisspeptin neurones express also neurokinin $B$ and dynorphin. By contrast to rodents where the RP3V and ARC respond to positive and negative sex steroid feedback respectively, the human infundibular nucleus relays signalling of both. It is, however, possible that the two processes are mediated by different neuronal populations.

The kisspeptin system seems also sexually dimorphic, although the critical period and origin of this dimorphism are still unknown. More kisspeptin fibres were detected in the infundibular nucleus and ventral periventricular area in women than in men (Hrabovszky et al., 2010). Sex differences were also reported in the number and expression of kisspeptin cell bodies, which are present in the rostral periventricular zone of the female only.

In addition, the recent study by Kurian et al. (2015) on mid to late pubertal ovarian intact female rhesus monkeys suggests that persistent exposures to BPA could impair the female reproductive function by directly influencing the hypothalamic neuroendocrine function as evidenced by an alteration of kisspeptin release and GnRH pulsatility.

The role of kisspeptin in the neuroendocrine control of the HPG axis is relevant to humans. Therefore, it can be considered that BPA-induced alterations of the hypothalamic kisspeptin/GnRH system are also relevant in humans.

\subsection{Evidence from human data of an ED MoA}

The association of BPA with altered hormonal levels in women has been investigated in a few epidemiological studies of good quality.

In a prospective study by Mok-Lin et al. (2010), which included women $(n=84)$ following an ovarian stimulation protocol as part of an in vitro fertilization (112 IVF cycles), the authors indicated that there was a negative correlation between urinary levels of BPA $(n=203$ urine samples; 2 samples per cycle during 91 cycles and one sample per cycle during 21 cycles of IVF) and ovarian response in terms of number of oocytes collected as 
well as amplitude of the preovulatory estradiol peak. A mean decrease of $12 \%$ in the number of oocytes recovered per cycle and of $213 \mathrm{pg} / \mathrm{mL}$ from the estradiol peak was observed for each log unit increase of urinary SG-BPA (BPA specific gravity, i.e., the BPA concentration corrected by the urine specific gravity). The BPA levels found were compared to urinary BPA concentrations observed in the general population in the NHANES 2003-2008 cohort. The concentration of urinary BPA found reflects BPA exposure at the time of collection, but not during the period of follicular maturation several months earlier. In addition, it is noted that it may be difficult to extrapolate the results observed in a sample of infertile women undergoing an in vitro fertilisation to the general population.

Nevertheless, the results were consistent with those observed in another more recent study.

Ehrlich et al. (2012) studied the association between urinary BPA concentrations and early reproductive outcomes among 174 women aged $18-45$ years representing a total of 237 IVF cycles at a fertility center in Boston, USA. The study was a follow up of Bloom et al. (2011), who previously reported an association between urinary BPA and decreased ovarian response (peak serum $E_{2}$ and oocyte count at the time of retrieval) in women undergoing IVF. After adjustment for age and other confounding parameters (Day 3 serum FSH, smoking, BMI), there was a linear dose-response association between increased urinary BPA concentrations and decreased number of oocytes (overall and mature), decreased number of normally fertilised oocytes and decreased $E_{2}$ levels (mean decreases of 40,253 and $471 \mathrm{pg} / \mathrm{ml}$ for urinary BPA quartiles 2, 3 and 4, when compared with the lowest quartile, respectively; $p$-value for trend $=0.001)$. Women with urinary BPA above the lowest quartile had decreased blastocyst formation (trend test Pvalue $=0.08$ ). The results from this extended study, using IVF as a model to study early reproductive health outcomes in humans, indicate a negative dose-response association between urinary BPA concentrations and serum peak $E_{2}$ and oocyte yield.

Souter et al. (2013) investigated the association between specific-gravity adjusted urinary BPA concentrations and number of antral follicles, day-3 serum $\mathrm{FSH}$, and ovarian volume among respectively 154, 120 and 114 women undergoing infertility treatments. After adjustment for age and BMI, there was a linear dose-response association between urinary BPA concentrations and a decrease of the number of antral follicles $(-12 \%(95 \%$ CI: $-23 \%,-0.6 \%),-22 \%(-31 \%,-11 \%)$, and $-17 \%(-27 \%,-6 \%)$, in the 2 nd, 3rd, and 4th BPA quartile compared to the 1st quartile). No association between BPA and FSH serum levels or ovarian volume.

Despite the fact that these studies were limited to a specific group of women with fertility disorders and despite the inherent limitations of epidemiological studies investigating exposure to a substance with short half-life, these studies provide some indications supporting the ability of BPA to alter hormonal regulation in humans.

\subsection{Overall conclusion on differences and commonalities}

Differences between rodents and humans in the regulation of cycles are identified in relation to the role of circadian synchronisation and to differences in the timing of ontogeny of the neuroendocrine axis and ovarian steroidogenesis. It is noteworthy however, that despites this difference in he temporal scheme of those events, the key principles of endocrine mechanisms of regulation of the cycle are preserved across mammalian species and in particular between rodents and humans. Overall, these elements bring support to the conclusion that the effects of BPA on disruption of cycles evidenced in rodents are relevant for humans.

In particular, both components that are shown to be involved in the endocrine MoA of BPA on cycle disturbance, i.e. the role of aromatase in estrogen production and the role of kisspeptin neurons in the ontogeny of the HPG axis are known to be relevant to 
human reproductive physiology.

\section{Discussion}

In both primates and non-primate mammals, follicle selection, growth, and maturation, as well as ovulation, oocyte quality, and subsequent corpus luteum function, all depend on subtle sequential actions of gonadotropins and intraovarian regulators. Furthermore, the ovary and the hypothalamo-pituitary system are in permanent endocrine dialogue with each other. Consequently, any disturbances in the endo/para/autocrine activities of the ovary and/or the hypothalamus-pituitary system can lead to cycle disturbance.

In addition, the estrous cycle is a perfectly synchronised and timely event that relies on specific neuroendocrine circuitries. Those pathways differentiate during fetal life and are largely influenced by numerous factors and in particular the steroid environment of the fetus. Thus fetal exposure to compounds able to modify the fetal steroidogenic environment is very likely to result in estrous cycle disturbances after puberty.

This review clearly shows that exposure to BPA at the adult stage alters the endocrine steroidogenic function of the ovary and more specifically the production of estrogens by the follicle, potentially leading to disturbance in the estrous cycle. Although most of the reported evidence rely on rodent studies there are in vitro data showing the same negative effect of BPA on the estrogen production in the human follicle cells. Furthermore, an indication of a negative association between the ability of the follicle to produce estrogens and exposure to BPA was observed in women. The role of estrogens in the maintenance of the cycle is similar in rodents and humans. Thus, it is concluded that it is quite likely that BPA may alter the ovarian cycle in humans through the disruption of the endocrine activity of the ovarian follicle.

At the neuroendocrine level, BPA can also act during the perinatal/postnatal organisation or adult activation of the hypothalamus-pituitary system in rodents or primates. Because of the similarities in sex-steroid-induced regulation of this axis between humans and rodents, it is possible that the changes in kisspeptin, GnRH expression, activity or liberation and sex steroid receptor expression induced by developmental or adult exposure to BPA occur also in humans and therefore impact estrous cyclicity.

Table 7 summarises the documentation supporting the ED-mediated MoA of BPA proposed for each of the two different periods of exposure. It is likely that both MoA may simultaneously contribute to the effect observed during both periods of exposure but the present analysis has been focused on available lines of evidence.

Table 7: Summary table of proposed ED-mediated MoA of BPA on alteration of estrous cyclicity and its documentation

\begin{tabular}{|c|c|c|c|}
\hline $\begin{array}{l}\text { Mode of action } \\
\text { documented for }\end{array}$ & \multicolumn{2}{|c|}{ Underlying cellular/molecular events } & $\begin{array}{l}\text { Alteration of } \\
\text { organ/function }\end{array}$ \\
\hline $\begin{array}{l}\text { Alteration of sex } \\
\text { steroid ovarian } \\
\text { steroidogenesis } \\
\text { during adult } \\
\text { exposure }\end{array}$ & $\begin{array}{l}\text { Reduced expression and } \\
\text { activity of aromatase } \\
\text { - In vitro: Watanabe et } \\
\text { al., 2012; Kwintkiewicz } \\
\text { et al., 2010; Mansur et } \\
\text { al., 2016 } \\
\text { - In vivo: Lee et al., } 2013\end{array}$ & $\begin{array}{l}\text { Decreased estradiol levels } \\
\text { - In vitro: Zhou et al., } \\
\text { 2008; Peretz et al., } \\
\text { 2011; Mlynarcikova et } \\
\text { al., 2005; } \\
\text { Kwintkiewicz et al.,, } \\
\text { 2010; Mansur et al., } \\
2016 \\
\text { - In vivo: Lee et al., } \\
2013\end{array}$ & $\begin{array}{l}\text { Alteration of estrous } \\
\text { cyclicity } \\
\text { - In vivo: Lee et al., } \\
\text { 2013; Laws et al.,' } \\
\text { 2000; Ty et al., I' } \\
2008\end{array}$ \\
\hline
\end{tabular}




\begin{tabular}{|c|c|c|c|}
\hline $\begin{array}{l}\text { Alteration of } \\
\text { neuroendocrine } \\
\text { regulation/ } \\
\text { development of the } \\
\text { reproductive } \\
\text { function during } \\
\text { developmental } \\
\text { exposure }\end{array}$ & $\begin{array}{l}\text { Alteration of kisspeptin } \\
\text { expression } \\
\text { - In vitro: Klenke et al., } \\
2016 \\
\text { - In vivo: Cao et al., } \\
\text { 2012; Navarro et al., } \\
2009 ; \text { Xi et al., 2011; } \\
\text { Naulé et al., 2014; } \\
\text { Kurian et al., 2015 }\end{array}$ & $\begin{array}{l}\text { Alteration in GnRH and/or } \\
\text { LH secretion } \\
\text { - In vivo: Monje et al., } \\
\text { 2010; Fernández et } \\
\text { al., 2009; Viega-Lopez } \\
\text { et al., 2014; Kurian et } \\
\text { al., } 2015\end{array}$ & $\begin{array}{l}\text { Alteration of estrous } \\
\text { cyclicity } \\
\\
\text { - In vivo: Honma } \\
\text { et al., 2002; } \\
\text { Nikaido et al., } \\
\text { 2004; Wang et } \\
\text { al., 2014a; } \\
\text { Rubin et al., } \\
\text { 2001; Mendoza- } \\
\text { Rodríguez et al., } \\
\text { 2011; Patisaul } \\
\text { et al., 2014; } \\
\text { Delclos et al., } \\
\text { 2014; Nah et } \\
\text { al., 2011; } \\
\text { Adewale et al., } \\
\text { 2009; } \\
\text { Fernández et } \\
\text { al., 2009; Zaid } \\
\text { et al., 2014 }\end{array}$ \\
\hline
\end{tabular}

Table 8 provides an overview of the critical elements in the identification of an endocrine disruptor and how they are fulfilled for alteration of estrous cycle by BPA.

Table 8: Overview of the elements supporting the identification of an alteration of estrous cyclicity as an ED-mediated effect of BPA

\begin{tabular}{|c|c|c|c|}
\hline & Adverse effect & Plausible ED MoA & Human relevance \\
\hline Adult exposure & $\begin{array}{l}\text { Key study of Lee et } \\
\text { al., 2013* }\end{array}$ & $\begin{array}{l}\text { Direct link established with } \\
\text { reduction of estradiol } \\
\text { production through reduced } \\
\text { aromatase activity }\end{array}$ & $\begin{array}{l}\text { Hormonal regulation of cycles } \\
\text { highly conserved in mammals } \\
\text { Support from in vitro data in } \\
\text { human cells } \\
\text { Consistent with indications } \\
\text { from human data }\end{array}$ \\
\hline $\begin{array}{l}\text { Developmental } \\
\text { exposure }\end{array}$ & $\begin{array}{l}\text { Identified in several } \\
\text { studies*: Honma et } \\
\text { al., 2002; Nikaido et } \\
\text { al., 2004; Wang et } \\
\text { al., 2014a; Rubin et } \\
\text { al., 2001; Mendoza- } \\
\text { Rodríguez 2011; } \\
\text { Patisaul et al., } \\
\text { 2014; Delclos et al., } \\
\text { 2014; Nah et al., } \\
\text { 2011; Adewale et } \\
\text { al., 2009; Fernández } \\
\text { et al., 2009; Zaid et } \\
\text { al., 2014 }\end{array}$ & $\begin{array}{l}\text { Physiologically-based high } \\
\text { plausibility of alteration of } \\
\text { kisspeptin expression involved } \\
\text { in neuroendocrine control }\end{array}$ & $\begin{array}{l}\text { Role of kisspeptin identified in } \\
\text { humans } \\
\text { Support from non-human } \\
\text { primate data on BPA-MoA }\end{array}$ \\
\hline
\end{tabular}

It is well recognised that the effects of BPA on the reproductive function are more diverse in their expression than alteration of estrous cycles. However, the female cyclicity is highly dependent upon hormonal fine regulation and as so it represents a good indicator for the identification of the nature of BPA endocrine MoA on the reproductive function.

In conclusion, although many mechanisms of action remains to be discovered, the present overall database shows that an alteration of the regulation of estrogens is an essential pattern of the MoA of BPA's effect on estrous cyclicity and supports the identification of BPA as an ED in regulatory context such as the SVHC identification. 


\section{REFERENCES}

Adewale HB, Jefferson WN, Newbold RR, Patisaul HB. (2009) Neonatal Bisphenol-A Exposure Alters Rat Reproductive Development and Ovarian Morphology Without Impairing Activation of Gonadotropin-Releasing Hormone Neurons. Biology of Reproduction, 81, 690-699.

Akingbemi B, Sottas CM, Koulova AI, Klinefelter GR, Hardy MP. (2004) Inhibition of testicular steroidogenesis by the xenoestrogen Bisphenol $A$ is associated with reduced pituitary luteinizing hormone secretion and decreased steroidogenic enzyme gene expression in rat Leydig cells. Endocrinology 145, 592-603.

ANSES (2013). Risk assessment of Bisphenol A (BPA) on human health. March 2013.

Benachour N, Moslemi S, Sipahutar H, Seralini GE. (2007) Cytotoxic effects and aromatase inhibition by xenobiotic endocrine disrupters alone and in combination. Toxicol Appl Pharmacol, 222(2):129-40.

Berger RG, Shaw J, deCatanzaro D. (2008). Impact of acute bisphenol-A exposure upon intrauterine implantation of fertilized ova and urinary levels of progesterone and 17beta-estradiol. Reprod Toxicol, 26(2), 94-9.

Berger RG, Foster WG, deCatanzaro D. (2010) Bisphenol-A exposure during the period of blastocyst implantation alters uterine morphology and perturbs measures of estrogen and progesterone receptor expression in mice. Reproductive Toxicology, 30, 393-400.

Bloom MS, Kim D, Vom Saal FS, Taylor JA, Cheng G, Lamb JD, Fujimoto VY. (2011) Bisphenol $A$ exposure reduces the estradiol response to gonadotropin stimulation during in vitro fertilization. Fertil Steril, 96(3):672-677.

Cabaton NJ, Wadia PR, Rubin BS, Zalko D, Schaeberle CM, Askenase MH, Gadbois JL, Tharp AP, Whitt GS, Sonnenschein C, Soto AM. (2011) Perinatal Exposure to Environmentally Relevant Levels of Bisphenol-A Decreases Fertility and Fecundity in CD-1 Mice. Environmental Health Perspectives, 119, 547-552.

Cao J, Mickens JA, McCaffrey KA, Leyrer SM, Patisaul HB. (2012) Neonatal Bisphenol A exposure alters sexually dimorphic gene expression in the postnatal rat hypothalamus. Neurotoxicology, 33(1):23-36.

Cao J, Joyner L, Mickens JA, Leyrer SM, Patisaul HB. (2014). Sex-specific Esr2 mRNA expression in the rat hypothalamus and amygdala is altered by neonatal bisphenol $A$ exposure. Reproduction, 147(4):537-54.

Daniel-Carlier N, Harscoët E, Thépot D, Auguste A, Pailhoux E, Jolivet G. (2013) Gonad differentiation in the rabbit: evidence of species-specific features. PLoS One. 8(4):e60451. doi: 10.1371/journal.pone.0060451. Print 2013.

de Roux N, Genin E, Carel JC, Matsuda F, Chaussain JL, Milgrom E. (2003) Hypogonadotropic hypogonadism due to loss of function of the KiSS1-derived peptide receptor GPR54. Proc Natl Acad Sci U S A, 100(19):10972-6.

Delclos KB, Camacho L, Lewis SM, Vanlandingham MM, Latendresse JR, Olson GR, Davis KJ, Patton RE, Gamboa da Costa G, Woodling KA, Bryant MS, Chidambaram M, Trbojevich R, Juliar BE, Felton RP, Thorn BT. (2014) Toxicity evaluation of bisphenol A administered by gavage to Sprague Dawley rats from gestation day 6 through postnatal day 90. Toxicol Sci, 139(1):174-97 
ECHA (2014). Committee for Risk Assessment (RAC). Opinion proposing harmonised classification and labelling at EU level of Bisphenol $A ; 4,4$ '-isopropylidenediphenol. Adopted 14 march 2014. ECHA. Available at http://echa.europa.eu/documents/10162/777918ff-33b5-46ff-be89-2bdc406d34fa (accessed on 20 July 2017).

ECHA (2015). Opinion on an Annex XV dossier proposing restrictions on Bisphenol A. Compiled version prepared by the ECHA Secretariat of RAC's opinion (adopted 5 June 2015) and SEAC's opinion (adopted 4 December 2015).

EFSA (European Food Safety Agency). (2015) Scientific Opinion on the risks to public health related to the presence of bisphenol A (BPA) in foodstuffs, EFSA journal 13(1):3978.

Ehrlich S, Williams PL, Missmer SA, Flaws JA, Berry KF, Calafat AM, Ye X, Petrozza JC, Wright D, Hauser R. (2012) Urinary Bisphenol A Concentrations and Implantation Failure among Women Undergoing in Vitro Fertilization. Environmental Health Perspectives, 120 (7), 978-983.

Ema M, Fujii S, Furukawa M, Kiguchi M, Ikka T, Harazono A. (2001) Rat twogeneration reproductive toxicity study of bisphenol A. Reprod Toxicol, 15(5):505-23.

Ferguson SA, Law CD, Kissling GE. (2014) Developmental treatment with ethinyl estradiol, but not bisphenol $A$, causes alterations in sexually dimorphic behaviors in male and female Sprague Dawley rats. Toxicol Sci, 140(2):374-92.

Fernández M, Bianchi M, Lux-Lantos V, Libertun C. (2009) Neonatal exposure to bisphenol $A$ alters reproductive parameters and gonadotropin releasing hormone signaling in female rats. Environ Health Perspect, 117(5):757-62

Fernández M, Bourguignon N, Lux-Lantos V, Libertun C. (2010) Neonatal exposure to bisphenol $a$ and reproductive and endocrine alterations resembling the polycystic ovarian syndrome in adult rats. Environ Health Perspect. 118(9):1217-22.doi: 10.1289/ehp.0901257. Epub 2010 Apr 22.

Fowler PA, Anderson RA, Saunders PT, Kinnell H, Mason JI, Evans DB, Bhattacharya S, Flannigan S, Franks S, Monteiro A, O'Shaughnessy PJ. (2011) Development of steroid signaling pathways during primordial follicle formation in the human fetal ovary. J Clin Endocrinol Metab. 96(6):1754-62. doi:10.1210/jc.2010-2618. Epub 2011 Mar 23.

Franssen D, Gérard A, Hennuy B, Donneau AF, Bourguignon JP, Parent AS. (2016) Delayed Neuroendocrine Sexual Maturation in Female Rats After a Very Low Dose of Bisphenol A Through Altered GABAergic Neurotransmission and Opposing Effects of a High Dose. Endocrinology, 157(5):1740-50

Fujimoto VY, Kim D, vom Saal FS, Lamb JD, Taylor JA, Bloom MS. (2011) Serum unconjugated bisphenol A concentrations in women may adversely influence oocyte quality during in vitro fertilization. Fertility and Sterility, 95, 1816-1819.

Gámez JM, Penalba R, Cardoso N, Bernasconi PS, Carbone S, Ponzo O, Pandolfi M, Scacchi P, Reynoso R. (2015) Exposure to a low dose of bisphenol A impairs pituitary-ovarian axis in prepubertal rats: effects on early folliculogenesis. Environ Toxicol Pharmacol. 39(1):9-15 doi: 10.1016/j.etap.2014.10.015

Greco TL, Payne AH. (1994) Ontogeny of expression of the genes for steroidogenic enzymes P450 side-chain cleavage, 3 beta-hydroxysteroid dehydrogenase, P450 17 alpha-hydroxylase/C17-20 lyase, and P450 aromatase in fetal mouse gonads. Endocrinology. 135(1):262-8. 
Heindel JJ, Newbold RR, Bucher JR, Camacho L, Delclos KB, Lewis SM, Vanlandingham M, Churchwell MI, Twaddle NC, McLellen M, Chidambaram M, Bryant M, Woodling K, Gamboa da Costa G, Ferguson SA, Flaws J, Howard PC, Walker NJ, Zoeller RT, Fostel J, Favaro C, Schug TT. (2015) NIEHS/FDA CLARITY-BPA research program update. Reprod Toxicol. 58:33-44. doi: 10.1016/j.reprotox.2015.07.075. Epub 2015 Jul 29. Review.

Hiyama M, Choi EK, Wakitani S, Tachibana T, Khan H, Kusakabe KT, Kiso Y. (2011) Bisphenol-A (BPA) affects reproductive formation across generations in mice. J Vet Med Sci, 73(9), 1211-5.

Honma S, Suzuki A, Buchanan DL, Katsu Y, Watanabe H, Iguchi T. (2002) Low dose effect of in utero exposure to bisphenol $A$ and diethylstilbestrol on female mouse reproduction. Reproductive Toxicology, 16, 117-122.

Hrabovszky E, Ciofi P, Vida B, Horvath MC, Keller E, Caraty A, Bloom SR, Ghatei MA, Dhillo WS, Liposits Z, Kallo I. (2010) The kisspeptin system of the human hypothalamus: sexual dimorphism and relationship with gonadotropin-releasing hormone and neurokinin B neurons. Eur J Neurosci, 31(11):1984-98.

Huang $\mathrm{H}$ and Leung LK. (2009) Bisphenol A downregulates CYP19 transcription in JEG-3 cells. Toxicol Lett, $28 ; 189(3): 248-52$.

Hunt PA, Lawson C, Gieske M, Murdoch B, Smith H, Marre A, Hassold T, VandeVoort CA. (2012) Bisphenol A alters early oogenesis and follicle formation in the fetal ovary of the rhesus monkey. Proc Natl Acad Sci U S A. 109(43):17525-30 doi: $10.1073 /$ pnas. 1207854109

JRC (2013). Key Scientific issues relevant to the identification and characterisation of endocrine disrupting substances - Report of the Endocrine Disruptors Expert Advisory Group (ED EAG). Eds. Munn S. and Gourmenou M. Pp 32. Available at: https://ec.europa.eu/jrc/en/publication/eur-scientific-and-technical-researchreports/key-scientific-issues-relevant-identification-and-characterisation-endocrinedisrupting (accessed on 20 July 2017).

Jukic AM, Calafat AM, McConnaughey DR, Longnecker MP, Hoppin JA, Weinberg CR, Wilcox AJ, Baird DD. (2015) Urinary Concentrations of Phthalate Metabolites and Bisphenol A and Associations with Follicular-Phase Length, Luteal-Phase Length, Fecundability, and Early Pregnancy Loss. Environ Health Perspect,124(3):321-8.

Kato H, Ota T, Furuhashi T, Ohta Y, Iguchi T. (2003) Changes in reproductive organs of female rats treated with BPA during the neonatal period. Reprod Toxicol, $17(3): 283-8$.

Kauffman AS, Gottsch ML, Roa J, Byquist AC, Crown A, Clifton DK, Hoffman GE, Steiner RA, Tena-Sempere M. (2007) Sexual differentiation of Kiss1 gene expression in the brain of the rat. Endocrinology, 148(4):1774-83.

Klenke U, Constantin S, Wray S. (2016) BPA Directly Decreases GnRH Neuronal Activity via Noncanonical Pathway. Endocrinology, 157(5):1980-90.

Kortenkamp A, Martin O, Faust M, Evans R, McKinlay R, Orton F, Rosivatz E. (2012) State of the art assessment of endocrine disrupters. Final report. Available at http://ec.europa.eu/environment/chemicals/endocrine/pdf/sota edc final report.pdf (accessed on 20 July 2017).

Kurian JR, Keen KL, Kenealy BP, Garcia JP, Hedman CJ, Terasawa E. (2015) Acute Influences of Bisphenol A Exposure on Hypothalamic Release of GonadotropinReleasing Hormone and Kisspeptin in Female Rhesus Monkeys. Endocrinology, 156(7):2563-70. 
Kwintkiewicz J, Nishi Y, Yanase T, Giudice LC. (2010) Peroxisome proliferatoractivated receptor gamma mediates the endocrine disrupter bisphenol a inhibition of fsh stimulated igf-i, aromatase and estradiol in human granulosa cells. Environ Health Perspect, 118 : 400-406

Kwon S, Stedman DB, Elswick BA, Cattley RC, Welsch F. (2000) Pubertal development and reproductive functions of $\mathrm{Crl}: \mathrm{CD}$ BR Sprague-Dawley rats exposed to bisphenol A during prenatal and postnatal development. Toxicological Sciences, $55,399-406$.

Laws SC, Carey SA, Ferrell JM, Bodman GJ, Cooper RL. (2000) Estrogenic activity of octylphenol, nonylphenol, bisphenol A and methoxychlor in rats. Toxicol Sci, 54:154167

Lee SG, Kim JY, Chung JY, Kim YJ, Park JE, Oh S, Yoon YD, Yoo KS, Yoo YH, Kim JM. (2013) Bisphenol A exposure during adulthood causes augmentation of follicular atresia and luteal regression by decreasing $17 \beta$-estradiol synthesis via downregulation of aromatase in rat ovary. Environ Health Perspect, 121(6):663-9

Li Y, Zhang W, Liu J, Wang W, Li H, Zhu J, Weng S, Xiao S, Wu T. (2014) Prepubertal bisphenol A exposure interferes with ovarian follicle development and its relevant gene expression. Reprod Toxicol. 44:33-40 doi: 10.1016/j.reprotox.2013.09.002

Losa-Ward SM, Todd KL, McCaffrey KA, Tsutsui K, Patisaul HB. (2012) Disrupted organization of RFamide pathways in the hypothalamus is associated with advanced puberty in female rats neonatally expodes to BPA. Biol Reprod, 87(2):28

Mansur A, Adir M, Yerushalmi G, Hourvitz A, Gitman H, Yung Y, Orvieto R, Machtinger R. (2016) Does BPA alter steroid hormone synthesis in human granulosa cells in vitro? Hum Reprod, 31(7):1562-9.

Mendoza-Rodríguez CA, García-Guzmán M, Baranda-Avila N, Morimoto S, PerrotApplanat M, Cerbón M. (2011) Administration of bisphenol A to dams during perinatal period modifies molecular and morphological reproductive parameters of the offspring. Reproductive Toxicology, 31, 177-183.

Milligan SR, Khan O, Nash M. (1998) Competitive binding of xenobiotic oestrogens to rat alpha-fetoprotein and to sex steroid binding proteins in human and rainbow trout (Oncorhynchus mykiss) plasma. Gen Comp Endocrinol. 112(1):89-95.

Mlynarcikova A, Kolena J, Ficková M, Scsuková S. (2005) Alterations in steroid hormone production by porcine ovarian granulosa cells caused by bisphenol $A$ and bisphenol A dimethacrylate. Mol. Cell. Endocrinol, 244:57-62.

Mok-Lin E, Ehrlich S, Williams PL, Petrozza J, Wright DL, Calafat AM, Ye X, Hauser R. (2010) Urinary bisphenol A concentrations and ovarian response among women undergoing IVF. International Journal of Andrology, 33, 385-393.

Monje L, Varayoud J, Muñoz-de-Toro M, Luque EH, Ramos JG. (2009) Neonatal exposure to bisphenol A alters estrogen-dependent mechanisms governing sexual behavior in the adult female rat. Reproductive Toxicology, 28 (4): 435-442.

Monje L, Varayoud J, Muñoz-de-Toro M, Luque EH, Ramos JG. (2010) Exposure of neonatal female rats to bisphenol A disrupts hypothalamic LHRH pre-mRNA processing and estrogen receptor alpha expression in nuclei controlling estrous cyclicity. Reprod Toxicol, 30(4):625-34.

Moore-Ambriz TR, Acuña-Hernández DG, Ramos-Robles $B$, Sánchez-Gutiérrez $M$, Santacruz-Márquez R, Sierra-Santoyo A, Piña-Guzmán B, Shibayama M, HernándezOchoa I. (2015) Exposure to bisphenol $A$ in young adult mice does not alter ovulation 
but does alter the fertilization ability of oocytes. Toxicol Appl Pharmacol, 289(3):50714.

Nah WH, Park MJ, Gye MC. (2011). Effects of early prepubertal exposure to bisphenol $A$ on the onset of puberty, ovarian weights, and estrous cycle in female mice. Clin Exp Reprod Med, 38(2), 75-81.

Nativelle-Serpentini C, Richard S, Séralini GE, Sourdaine P. (2003) Aromatase activity modulation by lindane and bisphenol-A in human placental JEG-3 and transfected kidney E293 cells. Toxicol In Vitro, 17(4):413-22.

Naulé L, Picot M, Martini M, Parmentier C, Hardin-Pouzet H, Keller M, Franceschini I, Mhaouty-Kodja S. (2014) Neuroendocrine and behavioral effects of maternal exposure to oral bisphenol A in female mice. J Endocrinol, 10;220(3):375-88.

Navarro VM, Sánchez-Garrido MA, Castellano JM, Roa J, García-Galiano D, Pineda R, Aguilar E, Pinilla L, Tena-Sempere M. (2009). Persistent impairment of hypothalamic KiSS-1 system after exposures to estrogenic compounds at critical periods of brain sex differentiation. Endocrinology, 150, 2359-2367

Newbold RR, Jefferson WN, Padilla-Banks E (2007) Long-term adverse effects of neonatal exposure to bisphenol $A$ on the murine female reproductive tract. Reproductive Toxicology, 24, 253-258.

Newbold RR, Jefferson WN, Padilla-Banks E (2009) Prenatal Exposure to Bisphenol A at Environmentally Relevant Doses Adversely Affects the Murine Female Reproductive Tract Later in Life. Environmental Health Perspectives, 117, 879-885.

Nikaido Y, Yoshizawa K, Danbara N, Tsujita-Kyutoku M, Yuri T, Uehara N, Tsubura A. (2004) Effects of maternal xenoestrogen exposure on development of the reproductive tract and mammary gland in female CD-1 mouse offspring. Reproductive Toxicology 18, 803-811.

Nikaido Y, Danbara N, Tsujita-Kyutoku M, Yuri T, Uehara N, Tsubura A. (2005) Effects of prepubertal exposure to xenoestrogen on development of estrogen target organs in female CD-1 mice. In Vivo, 19, 487-494.

NTP (1985) Bisphenol A: reproduction and fertility assessment in CD-1 mice when administered in the feed. NTP-85-192. Research Triangle Park, NC.

Patisaul HB, Todd KL, Mickens JA, Adewale HB. (2009). Impact of neonatal exposure to the ERalpha agonist PPT, bisphenol-A or phytoestrogens on hypothalamic kisspeptin fiber density in male and female rats. Neurotoxicology, 30(3), 350-7.

Patisaul HB, Mabrey N, Adewale HB, Sullivan AW. (2014) Soy but not bisphenol A (BPA) induces hallmarks of polycystic ovary syndrome (PCOS) and related metabolic co-morbidities in rats. Reprod Toxicol, 49:209-18.

Payen E, Pailhoux E, Abou Merhi R, Gianquinto L, Kirszenbaum M, Locatelli A, Cotinot C. (1996) Characterization of ovine SRY transcript and developmental expression of genes involved in sexual differentiation. Int J Dev Biol. 40(3):567-75.

Peretz J, Gupta RK, Singh J, Hernández-Ochoa I, Flaws JA. (2011) Bisphenol A impairs follicle growth, inhibits steroidogenesis, and downregulates rate-limiting enzymes in the estradiol biosynthesis pathway. Toxicol Sci, 119(1):209-17.

Peretz J and Flaws JA. (2013) Bisphenol A down-regulates rate-limiting Cyp11a1 to acutely inhibit steroidogenesis in cultured mouse antral follicles. Toxicol Appl Pharmacol, 271(2):249-56. 
Picon R, Pelloux MC, Benhaim A, Gloaguen F. (1985) Conversion of androgen to estrogen by the rat fetal and neonatal female gonad: effects of dcAMP and FSH. J Steroid Biochem. 23(6A):995-1000.

Richards J.S. Female reproductive system section. In Physiology of Reproduction. Knobill \& Neill Eds, Esevier Academic press, third edition, 2006, vol 1 pp 313-770

Rebuli ME, Cao J, Sluzas E, Delclos KB, Camacho L, Lewis SM, Vanlandingham MM, Patisaul HB. (2014) Investigation of the effects of subchronic low dose oral exposure to bisphenol A (BPA) and ethinyl estradiol (EE) on estrogen receptor expression in the juvenile and adult female rat hypothalamus. Toxicol Sci, 140(1):190-203.

Rivera OE, Varayoud J, Rodríguez HA, Muñoz-de-Toro M, Luque EH. (2011) Neonatal exposure to bisphenol A or diethylstilbestrol alters the ovarian follicular dynamics in the lamb. Reprod Toxicol, 32(3):304-12.

Rivera OE, Varayoud J, Rodríguez HA, Santamaría CG, Bosquiazzo VL, Osti M, Belmonte NM, Muñoz-de-Toro M, Luque EH. (2015) Neonatal exposure to xenoestrogens impairs the ovarian response to gonadotropin treatment in lambs. Reproduction, 149(6):645-55.

Rodríguez HA, Santambrosio N, Santamaría CG, Muñoz-de-Toro M, Luque EH. (2010) Neonatal exposure to bisphenol $A$ reduces the pool of primordial follicles in the rat ovary. Reprod Toxicol, 30(4):550-7.

Rubin BS, Murray MK, Damassa DA, King JC, Soto AM. (2001) Perinatal exposure to low doses of bisphenol A affects body weight, patterns of estrous cyclicity, and plasma LH levels. Environmental Health Perspectives, 109, 675-680.

Santamaría C, Durando M, Muñoz de Toro M, Luque EH, Rodríguez HA. (2016) Ovarian dysfunctions in adult female rat offspring born to mothers perinatally exposed to low doses of bisphenol A. J Steroid Biochem Mol Biol. 158:220-30 doi: 10.1016/j.jsbmb.2015.11.016

Savabieasfahani M, Kannan K, Astapova O, Evans NP, Padmanabhan V. (2006) Developmental programming: Differential effects of prenatal exposure to bisphenol-A or methoxychlor on reproductive function. Endocrinology 147, 5956-5966.

Seminara SB, Messager S, Chatzidaki EE, Thresher RR, Acierno JS Jr, Shagoury JK, Bo-Abbas Y, Kuohung W, Schwinof KM, Hendrick AG, Zahn D, Dixon J, Kaiser UB, Slaugenhaupt SA, Gusella JF, O'Rahilly S, Carlton MB, Crowley WF Jr, Aparicio SA, Colledge WH. (2003) The GPR54 gene as a regulator of puberty. N Engl J Med. 349(17):1614-27.

Signorile PG, Spugnini EP, Mita L, Mellone P, D'Avino A, Bianco M, Diano N, Caputo L, Rea F, Viceconte R, Portaccio M, Viggiano E, Citro G, Pierantoni R, Sica V, Vincenzi B, Mita DG, Baldi F, Baldi A. (2010) Pre-natal exposure of mice to bisphenol A elicits an endometriosis-like phenotype in female offspring. General and Comparative Endocrinology 168, 318-325.

Simpson ER, Mahendroo MS, Means GD, Kilgore MW, Hinshelwood MM, GrahamLorence S, Amarneh B, Ito Y, Fisher CR, Michael MD, et al. (1994) Aromatase cytochrome P450, the enzyme responsible for estrogen biosynthesis. Endocr Rev. $15(3): 342-55$

Skorupskaite K, George JT, Anderson RA. (2014) The kisspeptin-GnRH pathway in human reproductive health and disease. Hum Reprod Update. 20(4):485-500. 
Small CM, Manatunga AK, Klein M, Feigelson HS, Dominguez CE, McChesney R, Marcus M. (2006) Menstrual cycle characteristics: associations with fertility and spontaneous abortion. Epidemiology 17(1):52-60.

Smith MS, Freeman ME, Neill JD. (1975). The control of progesterone secretion during the estrous cycle and early pseudopregnancy in the rat: prolactin, gonadotropin and steroid levels associated with rescue of the corpus luteum of pseudopregnancy. Endocrinology. 96(1):219-226

Souter I, Smith KW, Dimitriadis I, Ehrlich S, Williams PL, Calafat AM, Hauser R. (2013) The association of bisphenol-A urinary concentrations with antral follicle counts and other measures of ovarian reserve in women undergoing infertility treatments. Reprod Toxicol. 42:224-31. doi: 10.1016/j.reprotox.2013.09.008.

Takagi H, Shibutani M, Masutomi N, Uneyama C, Takahashi N, Mitsumori K, Hirose M. (2004) Lack of maternal dietary exposure effects of bisphenol A and nonylphenol during the critical period for brain sexual differentiation on the reproductive/endocrine systems in later life. Arch Toxicol. 78:97-105.

Tinwell H, Haseman J, Lefevre PA, Wallis N, Ashby J. (2002) Normal sexual development of two strains of rat exposed in utero to low doses of bisphenol $A$. Toxicological Sciences 68, 339-348.

Tyl RW, Myers CB, Marr MC, Thomas BF, Keimowitz AR, Brine DR, Veselica MM, Fail PA, Chang TY, Seely JC, Joiner RL, Butala JH, Dimond SS, Cagen SZ, Shiotsuka RN, Stropp GD, Waechter JM. (2002) Three-generation reproductive toxicity study of dietary bisphenol A in CD Sprague-Dawley rats. Toxicological Sciences 68, 121-146.

Tyl RW, Myers CB, Marr MC, Sloan CS, Castillo NP, Veselica MM, Seely JC, Dimond SS, Van Miller JP, Shiotsuka RN, Beyer D, Hentges SG, Waechter JM Jr. (2008) Twogeneration reproductive toxicity study of dietary bisphenol a in CD-1 (Swiss) mice. Toxicological Sciences 104, 362-384.

Varayoud J, Ramos JG, Bosquiazzo VL, Lower M, Muñoz-de-Toro M, Luque EH. (2011). Neonatal exposure to bisphenol A alters rat uterine implantation-associated gene expression and reduces the number of implantation sites. Endocrinology. 152(3), 1101-11.

Veiga-Lopez A, Beckett EM, Abi Salloum B, Ye W, Padmanabhan V. (2014) Developmental programming: prenatal BPA treatment disrupts timing of LH surge and ovarian follicular wave dynamics in adult sheep. Toxicol Appl Pharmacol. 279(2):119-28

Wang W, Hafner KS, Flaws JA. (2014a) In utero bisphenol A exposure disrupts germ cell nest breakdown and reduces fertility with age in the mouse. Toxicol Appl Pharmacol. 276(2):157-64.

Wang X, Chang F, Bai Y, Chen F, Zhang J, Chen L. (2014b) Bisphenol A enhances kisspeptin neurons in anteroventral periventricular nucleus of female mice. J Endocrinol. 221(2):201-13.

Watanabe M, Ohno S, Nakajin S. (2012) Effects of bisphenol A on the expression of cytochrome P450 aromatase (CYP19) in human fetal osteoblastic and granulosa celllike cell lines. Toxicol Lett. 210(1):95-9.

Xi W, Lee CK, Yeung WS, Giesy JP, Wong MH, Zhang X, Hecker M, Wong CK. (2011) Effect of perinatal and postnatal bisphenol $A$ exposure to the regulatory circuits at the hypothalamus-pituitary-gonadal axis of CD-1 mice. Reprod Toxicol. 31(4):40917. 
Yoshida M, Shimomoto T, Katashima S, Watanabe G, Taya K, Maekawa A. (2004) Maternal exposure to low doses of bisphenol a has no effects on development of female reproductive tract and uterine carcinogenesis in Donryu rats. Journal of Reproduction and Development 50, 349-360.

Yu CJ, Fang QQ, Tai FD. (2015) Pubertal BPA exposure changes central ERa levels in female mice. Environ Toxicol Pharmacol. 40(2):606-14.

Zaid SS, Othman S, Kassim NM. (2014) Potential protective effect of Tualang honey on BPA-induced ovarian toxicity in prepubertal rat. BMC Complement Altern Med. 14:509.

Ziv-Gal A, Wang W, Zhou C, Flaws JA. (2015). The effects of in utero bisphenol A exposure on reproductive capacity in several generations of mice. Toxicol Appl Pharmacol 284(3):354-362.

Zhou W, Liu J, Liao L, Han S, Liu J. (2008) Effect of bisphenol A on steroid hormone production in rat ovarian theca-interstitial and granulosa cells. Mol. Cell. Endocrinol. 283:12-18 